\title{
The variability of peridotite composition across a mantle shear zone (Lanzo massif, Italy): interplay of melt focusing and deformation
}

\author{
M.-A. Kaczmarek • O. Müntener
}

Received: 3 June 2009/ Accepted: 31 January 2010/Published online: 19 February 2010

(C) Springer-Verlag 2010

\begin{abstract}
In this paper we present new data on the spatial variability of peridotite composition across a kilometerscale mantle shear zone within the Lanzo massif (Western Alps, Italy). The shear zone separates the central from the northern part of the massif. Plagioclase peridotite shows gradually increasing deformation towards the shear zone, from porphyroclastic to mylonitic textures in the central body, while the northern body is composed of porphyroclastic rocks. The peridotite displays a large range of compositions, from fertile peridotite to refractory harzburgite and dunite. Deformed peridotites (proto-mylonite and mylonites) tend to be compositionally more homogeneous and fertile than weakly deformed peridotites. The composition of most plagioclase peridotites show rather high and constant $(\mathrm{Ce} / \mathrm{Yb})_{N}$ ratios, and $\mathrm{Yb}_{N}$ that cannot be explained by any simple melting model. Instead,
\end{abstract}

Communicated by T. L. Grove.

Electronic supplementary material The online version of this article (doi:10.1007/s00410-010-0500-8) contains supplementary material, which is available to authorized users.

M.-A. Kaczmarek

Institute of Geology, University of Neuchâtel, rue Emile Argand, 2007 Neuchâtel, Switzerland

Present Address:

M.-A. Kaczmarek ( $\square)$

Géosciences Montpellier UMR 5243, CC60 Université

Montpellier 2 Place E. Bataillon,

34095 Montpellier Cedex 5, France

e-mail: mary-alix.kaczmarek@gm.univ-montp2.fr

\section{O. Müntener}

Institute of Mineralogy and Geochemistry,

University of Lausanne, Anthropôle,

1015 Lausanne, Switzerland refertilization modeling, consisting of melt increments from spinel peridotite sources, particularly with E-MORB melt, reasonably reproduces the plagioclase peridotite whole rock composition. Combined with constraints from $\mathrm{Ce}-\mathrm{Nb}$ and $\mathrm{Ce}-\mathrm{Th}$ systematics, we speculate that peridotites such as those from Lanzo record pervasive refertilization processes in the thermal boundary layer. In this scenario, mantle shear zones might act as important areas of melt focusing in the upper mantle that separates the thermal boundary layer from the conductively cooled mantle.

Keywords Plagioclase peridotite - Shear zone · Melt rock reaction - Melt focusing - Whole rock composition - Refertilization · Lanzo peridotite

\section{Introduction}

Studies on orogenic peridotites and mantle xenoliths proposed that melt migration and reaction is a major process in controlling the textures, mineralogy and geochemistry of mantle peridotite (e.g. Van der Wal and Bodinier 1996; Godard et al. 2000; Lenoir et al. 2000, 2001; Dijkstra et al. 2002; Piccardo et al. 2007a; Bodinier et al. 2008). For example, in Oman, the high-temperature mantle deformation and the distance from the Moho are correlated with the chemical composition of peridotite (Godard et al. 2000). In the Ronda massif a relatively sharp recrystallization front has been defined, interpreted to be formed during a magmatic event associated with infiltration of asthenospheric melts (Van der Wal and Bodinier 1996; Lenoir et al. 2001). Peridotites from the Massif Central originate from different levels marked by two sub-continental lithospheric mantle domains, texturally and chemically distinct (refractory 
coarse granular and fertile protogranular peridotite, respectively, e.g. Lenoir et al. 2000). Extensive refertilization is intrinsically related to lithospheric thinning processes in most of the Western Tethyan plagioclase peridotite (e.g. Müntener et al. 2004; Piccardo et al. 2004b). Recent studies on the Lanzo massif established that liquids produced by the upwelling asthenosphere migrated into the overlying peridotite and modified chemistry and texture (e.g. Müntener and Piccardo 2003). These examples illustrate that the chemical composition and texture of peridotite should track the interplay between melt percolation/impregnation and deformation processes.

Textures and mineral chemistry of many plagioclase peridotites are inconsistent with a residual origin and are interpreted as the product of impregnation with melt (Dijkstra et al. 2002; Müntener and Piccardo 2003). Substantial amounts of clinopyroxene, orthopyroxene, olivine and Al-phases (spinel, plagioclase) reacted with, and partially recrystallized from migrating melt (e.g. Müntener and Piccardo 2003; Seyler et al. 2003). Such a refertilization process was discussed by Elthon (1992) and Niu et al. (1997) for some abyssal peridotites and by Dick (1989) for some oceanic plagioclase peridotites. Recently, refertilization by basaltic or refractory melts has also been invoked for abyssal spinel peridotites (Hellebrand et al. 2002; Kelemen et al. 2004), which conventionally have been interpreted as simple residues of partial melting (Johnson et al. 1990; Johnson and Dick 1992). The distribution and abundance of melt-modified spinel and plagioclase peridotites within the ophiolitic peridotites of the Ligurian Tethys indicate that substantial volumes of pristine lithospheric mantle underwent these melt-related processes along the axial zone of the future basin (Piccardo et al. 2004a, b, 2007a). Reactive porous flow and refertilization are two important processes that are able to substantially modify textures, mineral modes and chemical compositions of peridotites (Van der Wal and Bodinier 1996; Bedini et al. 1997; Godard et al. 2000; Dijkstra et al. 2001; Müntener and Piccardo 2003; Piccardo et al. 2004b). The presence of small amounts of (interstitial) melt plays a key role in mantle dynamics. Indeed deformation is localized where melt is formed and/or transported. Experimental and numerical studies showed that during deformation melt is focused in an anastomosing network enclosing "melt-poor" lenses (Holtzman et al. 2003; Katz et al. 2006; Holtzman and Kohlstedt 2007). The presence of melt is known to substantially decrease the resistance to stress in solid state-flow (Hirth and Kohlstedt 1995), promotes recrystallization and may produce weakening. Permanent grain size reduction might occur in melt- and $\mathrm{H}_{2} \mathrm{O}$-free peridotites (Warren and Hirth 2006), but also in peridotites that were affected by melt-rock reaction (e.g. Dijkstra et al. 2002). Magmatic crystallization and shearing are frequently associated and suggest that fault systems and shear zones act as conduits for ascending magma (e.g. Hutton and Reavy 1992; Brown 1994; Rosenberg and Handy 2005; Kaczmarek and Müntener 2008).

The high temperature Alpine peridotites play a key role in identifying these processes. They have been classically considered as slightly depleted upper mantle material that rose as asthenospheric diapirs (Boudier and Nicolas 1972), and were interpreted to represent a possible source rock for MOR basalts (Beccaluva et al. 1984; Frey et al. 1985). Nicolas and Dupuy (1984) suggested that ophiolitic plagioclase lherzolite could be residual peridotite impregnated by a liquid with N-MORB composition. The heterogeneous composition of the oceanic lithosphere is influenced by a variety of melting processes (equilibrium vs. near fractional) and transport processes (pervasive porous flow vs. flow in chemically isolated conduits) (e.g. Nicolas 1989; Kelemen et al. 1995, 1997).

In this paper we present geochemical data on plagioclase peridotite, and its spatial relationship with an actively deforming shear zone. Our results indicate that the most deformed peridotite rocks display fertile compositions with overall less variability than porphyroclastic peridotites. We use simple geochemical and numerical models and discuss possible mechanisms to explain these observations. We test the refertilization hypothesis of the Lanzo massif during its exhumation. We propose that actively deforming high temperature shear zones in the mantle support melt focusing, and may act as important permeability barrier.

\section{Geological setting}

The Lanzo massif is located north-west of Torino, at the Po plain boundary (Fig. 1). The Lanzo massif is dominated by relatively fresh plagioclase peridotite surrounded by a serpentinite belt (Boudier and Nicolas 1972; Boudier 1978). Previous studies mapped the entire massif with the regional distribution of pyroxenite layering, high temperature foliations and gabbroic dikes (Boudier 1978; Boudier and Nicolas 1980). The massif has been subdivided into three parts, the northern, the central and the southern bodies. Each body was separated by shear zones oriented NW-SE and related to grain size reduction $(<200 \mu \mathrm{m})$ (Boudier 1972, 1978; Boudier and Nicolas 1972, 1980). In the northern and central parts of the massif, pyroxenites and high temperature foliation are mostly discordant while in the southern body they are concordant (Fig. 1). We focus our study on the northern shear zone, where the high temperature foliation and the layering are parallel; in contrast, the southern shear zone is discordant to the high temperature foliation and strongly serpentinized, indicating that the southern shear zone could be younger than the high 


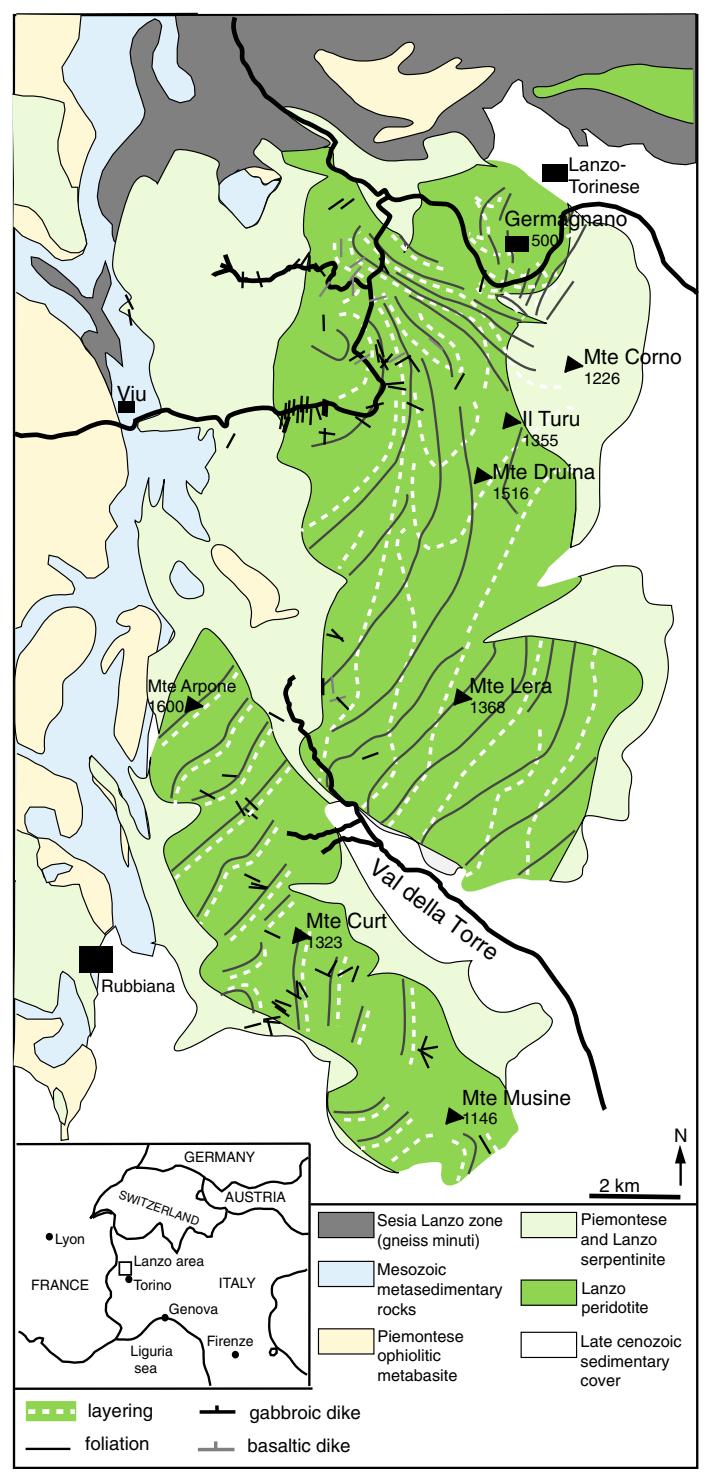

Fig. 1 Geological map of the Lanzo massif and its environment (modified from Boudier 1978). The box represents the studied area illustrated in Fig. 2

temperature deformation. The Lanzo massif is characterized by a regional-scale chemical and structural variation from the central to the northern part (Bodinier 1988; Kaczmarek and Müntener 2008). The shear zone between the northern and the central part of the massif displays five different types of microstructures (Fig. 2). In the field, the northern body appears to be much less deformed and is mapped as porphyroclastic peridotite (Figs. 2, 3). In the central part, the deformation increases and the grain size decreases from southwest to northeast, which corresponds to a change from porphyroclastic to mylonite with ultramylonite bands peridotite (Figs. 2, 3 and see more petrographic details in Kaczmarek and Müntener 2008). The porphyroclastic texture is characterized by a bimodal grain size distribution, containing weakly deformed porphyroclasts (olivine, orthopyroxene and clinopyroxene) with grain sizes exceeding $1 \mathrm{~cm}$, embedded in a matrix of recrystallized grains $(\sim 0.5 \mathrm{~mm}$ grain size $)$ made of olivine, orthopyroxene, plagioclase, clinopyroxene and spinel. The plagioclase is generally associated with pyroxenes as recrystallized grains with $120^{\circ}$ triple junctions or is surrounding $\mathrm{Cr}$-spinel. The porphyroclastic fine-grained texture displays a decreasing abundance and decreasing grain size of porphyroclasts $(<1 \mathrm{~cm})$, and increasing proportions of matrix minerals (Fig. 3). The proto-mylonite texture is characterized by further grain size reduction of porphyroclasts $(\sim 0.5 \mathrm{~mm})$ and the first occurrence of elongated orthopyroxene (aspect ratios exceeding 10:1). The matrix is composed of olivine, pyroxenes, spinel, and plagioclase with grain size ranging from 50 to $200 \mu \mathrm{m}$. The mylonite texture displays extremely stretched orthopyroxene (aspect ratios up to 20:1) and a fine-grained matrix $(5-50 \mu \mathrm{m})$ composed of pyroxenes, olivine, spinel and plagioclase. The plagioclase grains are larger than the other grains in the matrix with a grain size of $50 \mu \mathrm{m}$. The mylonite with ultra-mylonite bands (UMB) contains elongated porphyroclasts (olivine and pyroxenes) embedded in a very finegrained matrix $(5-15 \mu \mathrm{m})$ composed of olivine, pyroxenes, plagioclase, spinel and Ti-hornblende. The latter is present in most samples, in general around clinopyroxene, and is more abundant in the mylonite, and in particular in the ultra-mylonite bands and localized in the bands. In the proto-mylonite, mylonite and mylonite with UMB, the plagioclase is not always associated with spinel, but may form aggregates parallel to the foliation or isolated grains in the matrix. Porphyroclastic rocks are mapped south of the shear zone in the central body (porphyroclastic central: Pc) and form the bulk of the northern body (porphyroclastic north: Pn). The transition from the mylonite with ultra-mylonite bands to the northern porphyroclastic peridotites is relatively sharp. Strain is heterogeneously distributed and locally varies over small distances from a few tens to hundreds of meters. The contact area is located in the alluvial plain, and the distance between mylonite with UMB and porphyroclastic peridotite outcrops is less than $100 \mathrm{~m}$ (Fig. 2). The massif contains numerous MORB-type gabbroic dikes, which are preferentially found in the southern and central bodies (Figs. 1,2). They are weakly deformed and discordant to the main foliation. $\mathrm{U}-\mathrm{Pb}$ zircon ages of the gabbroic dikes constrain mylonite activity to be older than about $161 \mathrm{Ma}$ (Kaczmarek et al. 2008).

The Lanzo massif shows evidence of melt formation and melt extraction such as plagioclase-pyroxene clusters, plagioclase lenses and dunites (Boudier and Nicolas 1972; Müntener and Piccardo 2003; Piccardo et al. 2007a). Microstructures related to reactive fractionation of silicate liquids are found all over the Lanzo massif, particularly in the southern part (Boudier and Nicolas 1972; 1980; 


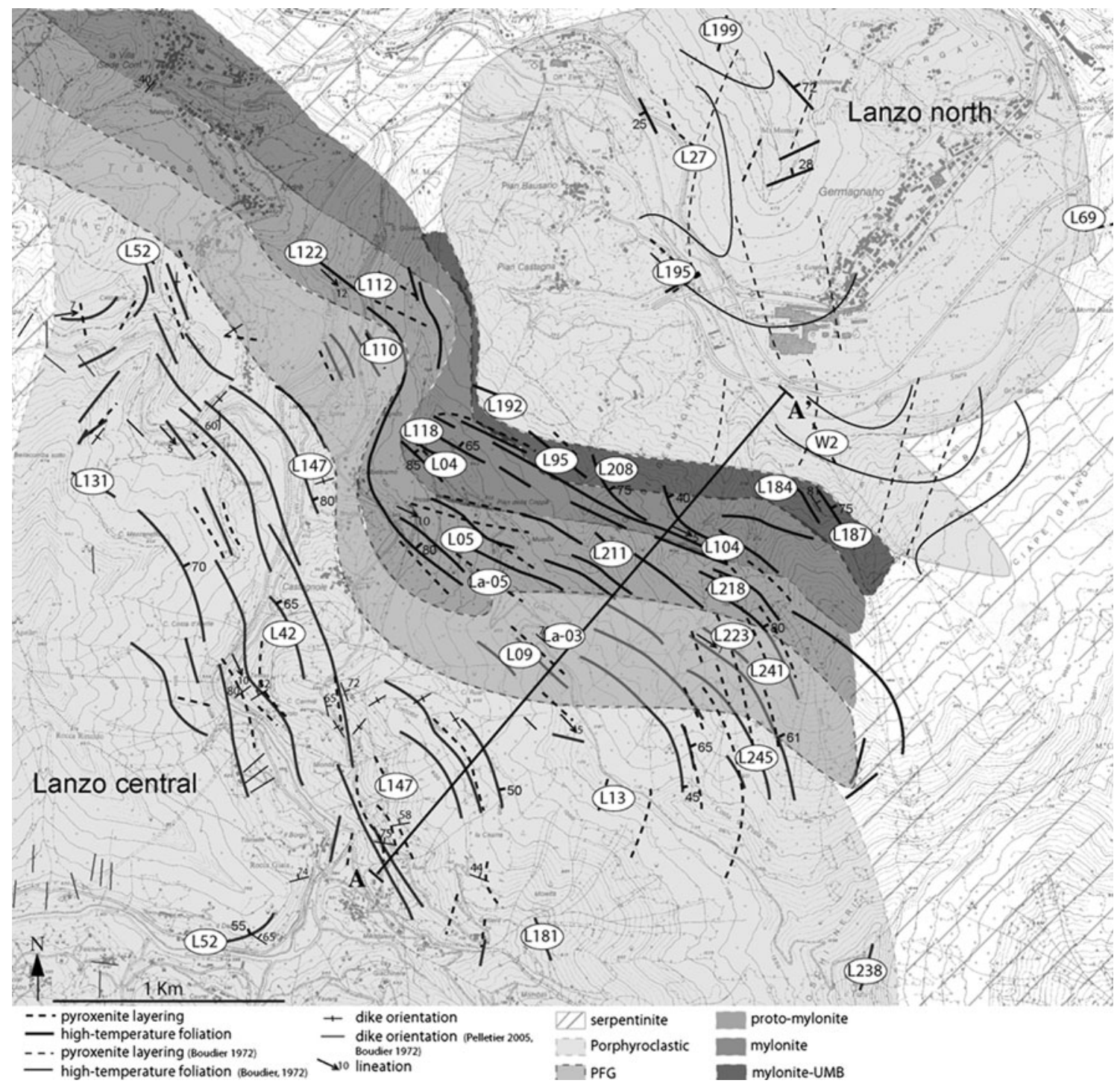

Fig. 2 Structural map of the shear zone between the northern and the central part of the Lanzo massif (from Kaczmarek and Müntener 2008). The peridotite and serpentinite boundaries, the five

Müntener and Piccardo 2003; Piccardo et al. 2004b, 2007a), indicating that melt migration is a regional-scale phenomenon. Evidence for melt/rock reaction can be observed in all peridotite types. Melt/rock reaction is expressed, by vermicular and interstitial, mostly exsolution-free orthopyroxene, localized along the contact with olivine and/or crosscutting larger porphyroclastic olivine and by exsolved porphyroclastic clinopyroxene partially replaced by intergrowths of orthopyroxene and plagioclase. These microstructures are preferentially preserved in weakly deformed rocks, or within large porphyroclasts in proto-mylonite or mylonite (for details on the textures and mineral chemistry, see Kaczmarek and Müntener 2008).

Earlier studies proposed that the Lanzo peridotite represents a residual piece of upper mantle after MORB deformation types, the main high temperature foliation and pyroxenite layering are shown. Samples are represented as numbers on the map. $P F G$ porphyroclastic fine-grained, $U M B$ ultra-mylonite bands

extraction (Bodinier 1988). The northern body is less depleted in LREE and has lower $\mathrm{Nd}$ and $\mathrm{Sr}$ isotope ratios than the southern body, which are similar to those of Atlantic MORB. The central body displays transitional geochemical features between the southern and the northern bodies (Bodinier et al. 1991). It was proposed that the northern body presents melt extraction lower than $6 \%$ and the lherzolite was equilibrated with T-MORB (Bodinier 1988). The central and southern domains present a variable percentage from $6 \%$ (central part) to $12 \%$ (south part) and have affinities with T to N-MORB (Pognante et al. 1985; Bodinier 1988; Bodinier et al. 1991). The southern body was interpreted as mantle asthenosphere, which rose from the garnet stability field as a high-temperature diapir emplaced at shallow levels, accompanied by a large degree of 


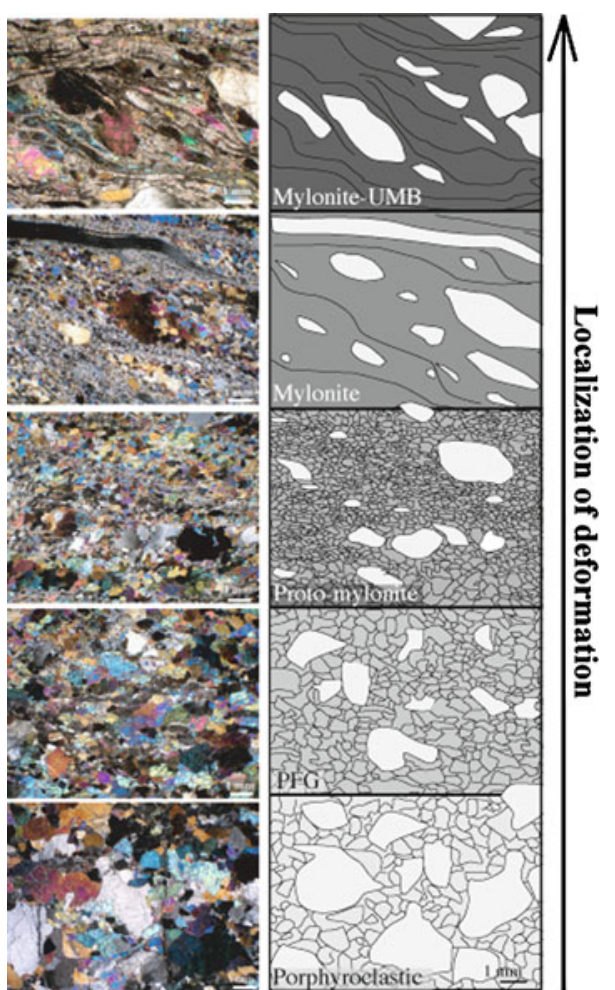

Fig. 3 Microphotographs and schematic illustrations representing 5 different deformation fabrics mapped (see Fig. 2 for distribution). The simplified illustrations indicate the localization of deformation increasing from porphyroclastic to mylonite with ultra-mylonite bands. The matrix microtexture is represented by a gray gradation, darker areas correspond to smaller grain size. $P F G$ porphyroclastic fine-grained, $U M B$ ultra-mylonite bands

melt extraction (Nicolas 1986; Bodinier et al. 1991). Recent studies propose that the pristine subcontinental lithospheric mantle is refertilized by thermo-chemical erosion produced by lithosphere/asthenosphere interaction in an extensional, pre-oceanic setting (Müntener and Piccardo 2003; Piccardo et al. 2007a). The northern body was interpreted as older depleted MORB mantle (DMM) material, as a piece of ancient sub-continental lithospheric mantle, which was separated from the convective mantle $\sim 700$ Ma years ago and accreted to sub-continental lithosphere (Bodinier et al. 1991; Piccardo et al. 2007b). The presence of refractory peridotite at shallow depth, are interpreted as bands of melt percolation (Bodinier 1988).

\section{Sample selection and analytical techniques}

Thirty-six samples of plagioclase peridotite were selected by location across the shear zone in relation to the deformation gradient (Fig. 2). Modal compositions for each lherzolite and some harzburgites are reported in eTable 1. Samples were selected for a preferentially low degree of serpentinization and a maximum distance from pyroxenite layering visible in the field.

In order to reduce contamination during sample preparation, all samples of $\sim 15 \mathrm{~cm}$ size were crushed and finally powdered in an agate mill. Whole rock glasses were prepared with the addition of Li-Tetraborate (dilution of 1:10). Peridotites were analyzed by Wavelength-dispersive X-ray fluorescence spectroscopy (XRF, Phillips PW 1404) at the University of Fribourg (Switzerland) and the results are presented in eTable 2 . The XRF trace element precision is generally better than $5 \%$. Peridotite whole rock trace elements (REE, $\mathrm{Cs}, \mathrm{Rb}, \mathrm{Th}, \mathrm{U}, \mathrm{Nb}, \mathrm{Ta}, \mathrm{Sr}, \mathrm{Zr}$ and $\mathrm{Hf}$ ) were analyzed by a VG-PQ2 Turbo + Inductively Coupled Plasma-Mass Spectrometer (ICP-MS) at Géosciences Montpellier (Université Montpellier II, France) and are reported in eTable 3. The REE, $\mathrm{Cs}, \mathrm{Rb}, \mathrm{Pb}, \mathrm{Th}, \mathrm{U}, \mathrm{Sr}, \mathrm{Zr}$ and $\mathrm{Hf}$ concentrations were determined by external calibration following the $\mathrm{HF} / \mathrm{HClO}_{4}$ dissolution and analytical procedure described in detail by Ionov et al. (1992). To avoid memory effects due to the intake of concentrated $\mathrm{Nb}-\mathrm{Ta}$ solutions in the instrument, $\mathrm{Nb}$ and $\mathrm{Ta}$ concentrations were determined by using $\mathrm{Zr}$ and $\mathrm{Hf}$, respectively, as internal standards. This technique is an implementation to ICP-MS analysis of the method described by Jochum et al. (1990). The precision and accuracy of the ICP-MS analyses including results obtained for rock standards PCC-1 and UBN, are given in Godard et al. (2008) and are added in eTable 3.

Trace element analyses on minerals were performed by Laser Ablation ICP-MS at the University of Lausanne (Switzerland). We used a pulsed $193 \mathrm{~nm}$ Excimer Laser system (Lambda Physik, Geolas $200 \mathrm{M}$ ), coupled with a quadrupole ICP-MS (Perkin Elmer DRC 6200), with operating conditions of $27 \mathrm{kV}$, and $10 \mathrm{~Hz}$ repetition rate, yielding a flux of ca $12 \mathrm{~J} / \mathrm{cm}^{2}$ on the ablation site. This laser system allows optimizing the beam size for analysis (8-120 $\mu \mathrm{m}$, adjusted via an aperture in the beam path) at constant energy density on the sample surface and perfect localization of analytical spots through a petrographic microscope using combined transmitted and reflected light. Helium was used as a carrier gas. The SRM 610 glass was chosen as an external standard, $\mathrm{Ca}$ as the internal standard, and data reduction employed the Glitter package (Van Achterbergh et al. 2001). BCR2 basaltic glass was used to monitor the reproducibility and accuracy of the system.

\section{Bulk rock chemistry}

\section{Major elements}

The studied peridotites display a range of $\mathrm{MgO}$ contents between 36.6 and $40.8 \mathrm{wt} \%$ that are negatively correlated 
with $\mathrm{SiO}_{2}, \mathrm{Al}_{2} \mathrm{O}_{3}, \mathrm{Na}_{2} \mathrm{O}, \mathrm{Ti}$ and $\mathrm{Cr}$ (Fig. $4 \mathrm{a}, \mathrm{SiO}_{2}$ as example). The $\mathrm{SiO}_{2}$ content is between 43.5 and $45.3 \mathrm{wt} \%$. Figure $4 \mathrm{a}$ reveals that the data of Bodinier (1988) present generally higher $\mathrm{SiO}_{2}(\sim 1 \mathrm{wt} \%$ higher $)$ than our analyses and the data of Piccardo et al. (2007a) present $\mathrm{MgO}$ contents higher than peridotite from this study (41-47 wt\%). Overall, our results are broadly consistent with previously published whole rock data.

The peridotites show a high $\mathrm{Al}_{2} \mathrm{O}_{3} / \mathrm{SiO}_{2}$ ratio (0.0490.090) similar to depleted plagioclase peridotite (Bodinier 1988; Rampone et al. 2005; Piccardo et al. 2007a) and have a typical peridotite $\mathrm{MgO} / \mathrm{SiO}_{2}$ ratio (Fig. 4b). Our data are close to the primitive mantle (PM) line (Jagoutz et al. 1979). The chemical composition highlights a large compositional variability of the porphyroclastic rocks, from $\mathrm{Al}_{2} \mathrm{O}_{3} / \mathrm{SiO}_{2}$ ratios that are rather low $(>0.028)$ similar to the refractory rocks of abyssal peridotite (Godard et al. 2000) to very high ratio (0.098 and 0.112). Some samples are enriched in $\mathrm{Al}_{2} \mathrm{O}_{3}$ and depleted in
$\mathrm{SiO}_{2}$ (Fig. 4b). The data of Piccardo et al. (2007a) present systematically higher $\mathrm{MgO} / \mathrm{SiO}_{2}$ ratios as compared to the PM line (Fig. 4a), and might reflect XRF $\mathrm{MgO}$ contents that are slightly too high. The peridotites analyzed by Bodinier (1988) show a trend parallel to our analyses on a slightly lower level, as a consequence of a generally higher $\mathrm{SiO}_{2}$ content at a given $\mathrm{MgO}$. The reason for this apparent discrepancy between different data sets is not known. Similar to other suites of mantle rocks the $\mathrm{Al}_{2} \mathrm{O}_{3} / \mathrm{CaO}$ ratio is constant and close to primitive mantle estimates (Fig. 4b). Some samples of plagioclase peridotite plot above the PM line with higher content in $\mathrm{Al}_{2} \mathrm{O}_{3}$.

The Lanzo plagioclase peridotites display little variation in the mg-number (molar $\mathrm{Mg} / \mathrm{Mg}+\mathrm{Fe}$ or $\mathrm{Mg \# ,} \mathrm{89-90,}$ Fig. 4c), but generally lower values than in abyssal peridotite (Mg\# > 91, e.g. Dick 1989).

The $\mathrm{Al}_{2} \mathrm{O}_{3}$ content scatters from 1.2 to $4.98 \mathrm{wt} \%$ (eTable 2) and the major variation is recorded in the
Fig. 4 Bulk rock major element composition of the shear zone illustrated in a $\mathrm{MgO}$ versus $\mathrm{SiO}_{2}$ (wt\%), b $\mathrm{Al}_{2} \mathrm{O}_{3}$ l $\mathrm{SiO}_{2}$ versus $\mathrm{MgO} / \mathrm{SiO}_{2}$ (wt $\%$ ), c $\mathrm{MgO}$ versus $\mathrm{FeO}$ (wt\%) and d $\mathrm{CaO}$ versus $\mathrm{Al}_{2} \mathrm{O}_{3}$ (wt\%). Published data from the Lanzo massif are shown for comparison: Bodinier (1988), Piccardo et al. (2007a, b). Abyssal peridotites are from Dick (1989). d Represents textural and chemical relationships from the Lanzo shear zone. The black line represents the silicate Earth differentiation trend and the primitive mantle ratio (PM) (Jagoutz et al. 1979) in b and d The solid lines in c show constant $\mathrm{Mg \#}$ values. In d, dashed lines represent constant $\mathrm{CaO} / \mathrm{Al}_{2} \mathrm{O}_{3}$
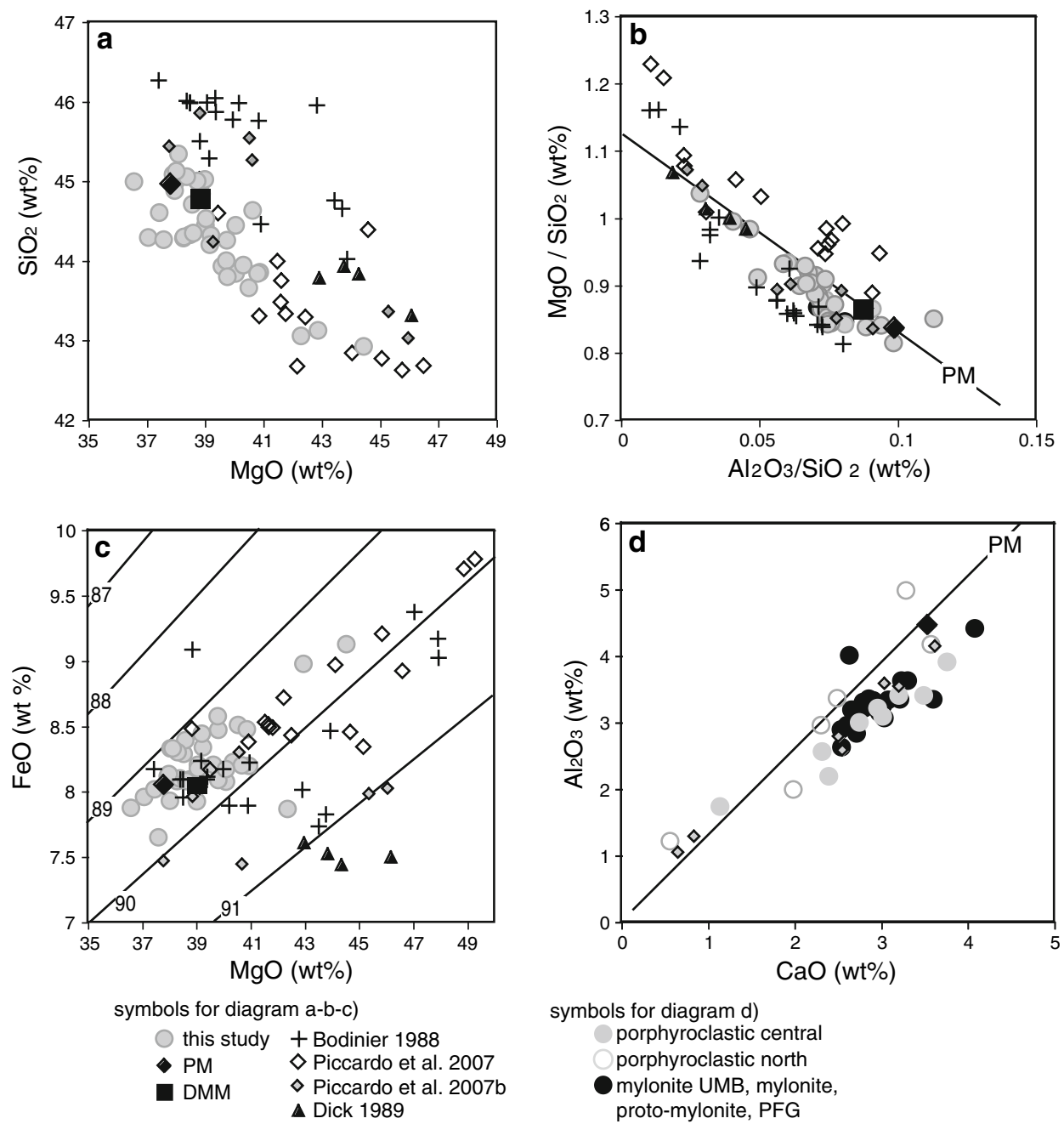

symbols for diagram d)

porphyroclastic central

porphyroclastic north

mylonite UMB, mylonite, proto-mylonite, PFG 
porphyroclastic rocks, particularly from the northern part of the massif (Fig. 4d). Three porphyroclastic samples, display fairly low $\mathrm{Al}_{2} \mathrm{O}_{3}$ content (below 2 wt $\%$ ) corresponding to harzburgitic or dunitic compositions. Recent analyses from the northern body of the Lanzo massif (Piccardo et al. 2007b) present a similar variability of $\mathrm{Al}_{2} \mathrm{O}_{3}$ (Fig. 4d). $\mathrm{MgO}, \mathrm{Na}_{2} \mathrm{O}, \mathrm{CaO}, \mathrm{FeO}, \mathrm{SiO}_{2}, \mathrm{Cr} \#$ and $\mathrm{TiO}_{2}$ decrease from porphyroclastic to deformed rocks (Figs. 6, 8).

\section{Rare earth elements}

The normalized REE and trace element patterns of the analyzed samples are shown in Fig. 5. The plagioclase lherzolites display trace element signatures characterized by weak LREE depletion and a relatively flat M-HREE pattern (Fig. 5). The patterns are similar in all rock types with little variation in the $(\mathrm{Ce} / \mathrm{Yb})_{N}$ ratio $(0.2-0.4)$. The absence of $\mathrm{Eu}$ anomalies indicates that significant plagioclase fractionation is unlikely.

The normalized primitive mantle composition plotted on the diagrams of Fig. 5 (McDonough and Sun 1995), shows a flat pattern and highlights elevated HREE enrichment of several samples. Such samples are found in all groups, except in the porphyroclastic peridotites. Mylonite samples with ultra-mylonitic bands display a rather homogeneous composition except sample L95, which is enriched in La (Fig. 5a). Two other samples (L104 and L103) from the mylonite group show a similar behavior with $(\mathrm{La} / \mathrm{Ce})_{N}>1$, apparently independent of the degree of serpentinization. Two samples from the mylonite group present heterogeneous composition: L118 with middle to heavy REE compositions exceeding primitive mantle values (e.g. $\mathrm{Lu}_{N}$ : 3.4 ) and $\mathrm{L} 103$ with a relatively depleted composition. The proto-mylonite group displays rather homogeneous compositions, with three samples equal to or higher (from $\mathrm{Gd}$ to $\mathrm{Lu}$ ) than PM (Fig. 5c). The LREE composition of porphyroclastic samples is more variable e.g. L241: $0.038 \mu \mathrm{g} / \mathrm{g} \mathrm{La}$; L212: $0.095 \mu \mathrm{g} / \mathrm{g} \mathrm{La}$ (Fig. 5d). Sample L212 is one of the samples enriched in HREE elements compared to the PM composition.

The coarse-grained peridotites from the northern and the central body display larger trace element variations (Fig. 5e, f). Relative to primitive mantle, some of the porphyroclastic peridotites from the Central body are enriched in HREE, while the porphyroclastic peridotites from the northern group are generally lower than primitive mantle. A few samples display low REE (Fig. 5e, f) with pattern similar to clinopyroxene-poor lherzolite described by Bodinier (1988) in the southern part of the massif. Sample W2 is clearly different from the general trend of plagioclase lherzolite, displaying low contents in all elements and a much smoother increase from $\mathrm{La}$ to $\mathrm{Lu}$, with a pattern similar to harzburgite described by Bodinier (1988).

\section{Other trace elements}

Similar to abyssal peridotite from the Pacific and Indian Ocean ridge-transform system (e.g. Bodinier and Godard 2003; Niu 2004), the Lanzo peridotites are characterized by U-shaped normalized trace element patterns, with no significant variation between different groups of deformation. These patterns present weak depletions of $\mathrm{Zr}$, Hf and LREE with respect to M- and HREE (Fig. 5). The trace element patterns show small but significant positive spikes in $\mathrm{Pb}$, with $(\mathrm{Ce} / \mathrm{Pb})_{N}$ of $0.08-1.40$, that are not accompanied by $\mathrm{Sr}$ spikes. The $\mathrm{Pb}$ content varies between 0.01 and $0.21 \mu \mathrm{g} / \mathrm{g}$ and is apparently independent of the deformation. The $\mathrm{Nb} / \mathrm{Ta}$ ratio $(11.6 \pm 3.5)$ is below the primitive mantle estimate (17.8, McDonough and Sun 1995). In addition, the peridotite displays $U$ enrichment relative to the neighboring elements, $\mathrm{Th}$ and $\mathrm{Nb}$. U/Th ratios vary between 0.18 and 3.12 as compared to $\mathrm{PM}$ (0.25). $\mathrm{Th} / \mathrm{Nb}$ varies from 0.01 to 0.27 , which is in the range of primitive mantle (0.12), and DMM (0.05) (McDonough and Sun 1995; Workman and Hart 2005). Plagioclase lherzolite from all different groups have homogeneous and flat patterns from $\mathrm{Pr}$ to $\mathrm{Lu}$, except for clinopyroxene-poor lherzolite samples L228 and W2, which generally show a lower concentration in all trace elements (Fig. 5k, 1). The elements $\mathrm{Cs}, \mathrm{Rb}$ and Ba display large variations on primitive mantle normalized diagrams (from $<0.1$ to $>1$ ). Several samples from the porphyroclastic rocks have a relatively high LOI (from 2.5 to 9.5 wt\%) and display either low or high contents in $\mathrm{Ba}$, Cs and $\mathrm{Rb}$ (eTable 3). We conclude that LILE elements might have been affected by serpentinization and/or highpressure metamorphism but otherwise these secondary processes had a minor influence on the overall bulk rock composition.

The chemical variations, with respect to deformation in terms of $\mathrm{Al}_{2} \mathrm{O}_{3}, \mathrm{Na}_{2} \mathrm{O}, \mathrm{TiO}_{2}, \mathrm{Ni}, \mathrm{Zr}, \mathrm{Sm}$ and $\mathrm{Yb}$ are illustrated in Fig. 6. It is apparent that the variability decreases from porphyroclastic to mylonitic rocks. The $\mathrm{Al}_{2} \mathrm{O}_{3}$ content in particular, illustrates a decreasing variability from porphyroclastic rocks (1.20-4.98 wt\%), protomylonite and PFG rocks (2.62-4.00 wt \%) to mylonite with UMB and mylonitic samples (2.83-3.62 wt \%). The $\mathrm{Na}_{2} \mathrm{O}$ variability is similar, and the deformed rocks show homogeneity of the composition while the deformed samples have a higher content than the porphyroclastic rocks (Fig. 6a). The $\mathrm{TiO}_{2}$ content is positively correlated with $\mathrm{Al}_{2} \mathrm{O}_{3}$ (Fig. 6b). The Ni content is uniform with increasing deformation and is higher in the mylonite with UMB and 
670

Contrib Mineral Petrol (2010) 160:663-679
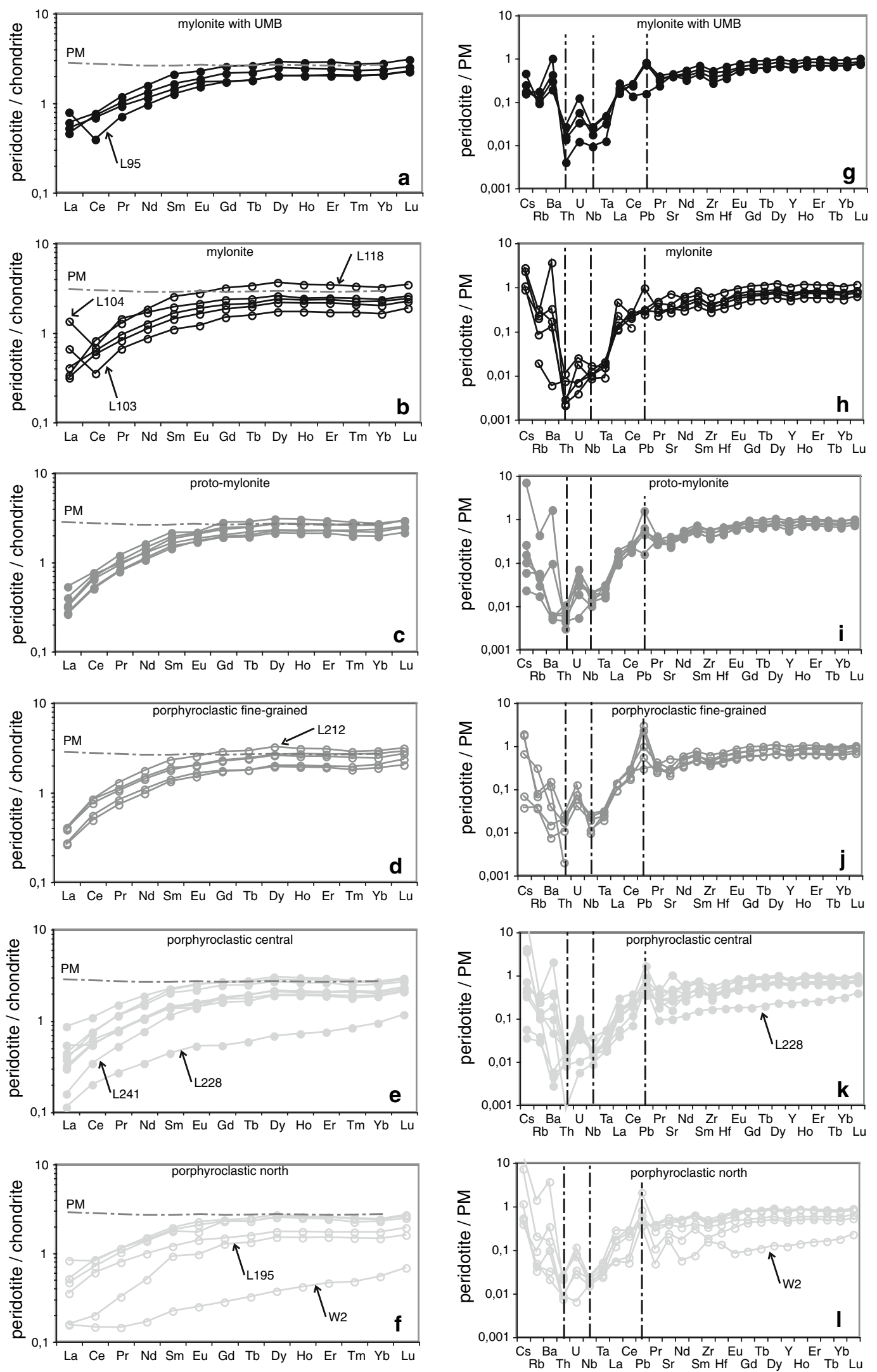

Springer 
4 Fig. 5 Plagioclase peridotite trace elements normalized to chondrite and primitive mantle (McDonough and Sun 1995) subdivided by deformation fabric from (a, g) mylonite with ultra-mylonite bands, (b, h) mylonite, (c, i) proto-mylonite, (d, j) PFG and (e, f, k, l) porphyroclastic from the northern and central body. $P M$ primitive mantle (McDonough and Sun 1995)

mylonite (from 2,100 to 2,400 $\mathrm{gg} / \mathrm{g}$, Fig. 6c). The $\mathrm{Zr}$ content displays less variation in the proto-mylonite and the fine-grained rocks compared to the porphyroclastic rocks (Fig. 6d).

\section{Mineral trace element chemistry}

In order to test whether the bulk rock variability is correlated with trace element mineral variability we measured in situ the trace element contents of clinopyroxene, orthopyroxene and plagioclase from ten samples (results are given in eTable 4, eFigure 1).

Porphyroclastic clinopyroxenes display relatively homogeneous compositions in all samples and the $(\mathrm{Ce} /$ $\mathrm{Yb})_{N}$ ratio ranging between 0.18 and $1.62 \mu \mathrm{g} / \mathrm{g}$. The rims of clinopyroxene indicate a La decrease, a weak negative Eu anomaly and a weak MREE enrichment (from Gd to Er) relative to the core. This chemical variation may reflect equilibration of clinopyroxene with plagioclase (eFig. 1a, $\mathrm{b}, \mathrm{f})$. This is well illustrated by disequilibrium reaction textures and crystallized orthopyroxene + plagioclase (eFig. 1e). One exception is the harzburgite sample (W2), which displays enriched LREE compositions, similar to metasomatized harzburgites (e.g. Bodinier and Godard 2003) or to pyroxenes reported by Piccardo et al. (2007a). Orthopyroxene cores display typical REE pattern with low LREE/HREE ratios $\left(\mathrm{Ce}_{N} / \mathrm{Yb}_{N} \sim 0.01\right)$ while orthopyroxene rims are generally lower in REE relative to core compositions (eFig. 1d-f). The interstitial orthopyroxene grains, which are interpreted as products of melt reaction with olivine or clinopyroxene (liquid + olivine $\rightarrow$ orthopyroxene; liquid + clinopyroxene $\rightarrow$ orthopyroxene + plagioclase), display REE pattern similar to porphyroclastic orthopyroxenes. The majority of orthopyroxene that is related to melt-rock reactions is enriched in HREE relative to core compositions, with $\mathrm{Er}_{N} / \mathrm{Yb}_{N}$ ratios between 0.11 and 0.25 , respectively (eFig. $1 \mathrm{~g}$ ). Orthopyroxene displays positive $\mathrm{Zr}$, Hf, Ti anomalies, a $\mathrm{Sr}$ negative anomaly relative to elements of similar compatibility (eFig. 1i-1). Orthopyroxene from harzburgite from the Northern Lanzo massif (sample W2) displays less fractionated compositions with a clear distinction between the three types of orthopyroxene (eFig. 1h-l), indicating trace element enrichment in this sample (see also Piccardo et al. 2007b). Both pyroxenes display rather low concentrations of fluid mobile elements ( $\mathrm{Rb}$ and $\mathrm{Ba}$ ) suggesting limited influence of serpentinization or fluid circulation during Alpine subduction and exhumation.

\section{Discussion}

Given the paucity of spatially controlled compositional and structural data of plagioclase peridotites, the observed variations of the Lanzo peridotites provide important constraints on the effect of deformation and melt migration on peridotite composition. In particular the spatial variations in bulk rock major and trace element contents may be related to a major structural discontinuity in mantle peridotites. Two distinct mechanisms may be proposed to explain this compositional boundary. One interpretation is that preexisting chemical heterogeneity in the mantle is erased by mechanical (and chemical) mixing and homogenization via deformation. Alternatively melt migrating by porous flow is focused beneath a structural discontinuity and starts to partially crystallize. Below, we use our chemical data, combined with previously published results to discuss these two alternatives.

\section{Bulk rock major element variability}

Plagioclase lherzolite from the Lanzo massif generally displays $\mathrm{Al}_{2} \mathrm{O}_{3}$ contents between 2 and $4 \mathrm{wt} \%$ (Bodinier 1988; Piccardo et al. 2007a). Lower concentrations are quite rare and are preferentially found in the southwestern part of the massif, where dunite and harzburgite are more abundant (Boudier and Nicolas 1972; Bodinier 1988). However, the dunites in the southern part postdate plagioclase peridotite formation (Piccardo et al. 2007a) and thus represent chemical heterogeneities that where introduced after the formation of plagioclase peridotites. In the present study we focus on the compositions of peridotite unrelated to late dunites, and in these rocks the $\mathrm{Al}_{2} \mathrm{O}_{3}$ content varies from 1.2 to $5.0 \mathrm{wt} \%$ encompassing a large spectrum ranging from refractory to 'superfertile' compositions. The variability of bulk rock major element composition of the Lanzo peridotite in the investigated area is correlated to the peridotite microstructure: increasing deformation from porphyroclastic to mylonitic rocks (Fig. 2) is associated with a more homogeneous composition $\left(\mathrm{Al}_{2} \mathrm{O}_{3}, \mathrm{TiO}_{2}, \mathrm{Na}_{2} \mathrm{O}\right.$ and $\left.\mathrm{NiO}\right)$. The porphyroclastic peridotites from the central and northern body generally display similar compositional variation, and the presence of depleted samples and pyroxenites indicates a heterogeneous mantle prior to deformation.

Major elements indicative of peridotite fertility (e.g., Al and $\mathrm{Ca}$ ), are uniformly high in deformed rocks and scatter less than porphyroclastic ones (Fig. 7). The average $\mathrm{Al}_{2} \mathrm{O}_{3}$ content calculated on each category of deformation 

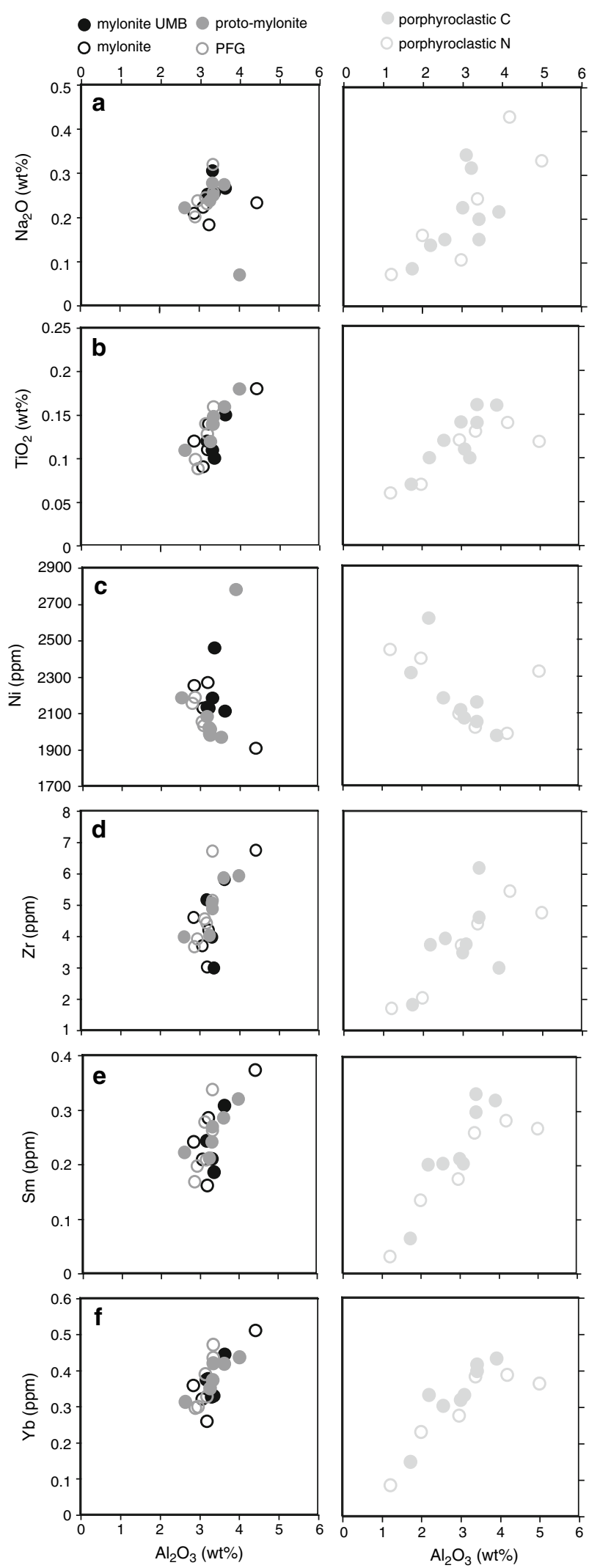

indicates about $10 \%$ higher content in mylonite with ultramylonite bands, mylonite and proto-mylonite than in the porphyroclastic rocks, although this variability is not
Fig. 6 Element variation diagrams of $\mathrm{Rb}$ (ppm), $\mathrm{Na}_{2} \mathrm{O}$ (wt\%), $\mathrm{TiO}_{2}$ (wt\%), $\mathrm{Ni}(\mathrm{ppm}), \mathrm{Zr}(\mathrm{ppm}), \mathrm{Sm}(\mathrm{ppm})$ and $\mathrm{Yb}(\mathrm{ppm})$ versus $\mathrm{Al}_{2} \mathrm{O}_{3}$ (wt\%). The columns present the data according to microstructural criteria. Note that there is almost no correlation between $\mathrm{Al}_{2} \mathrm{O}_{3}$ and a variety of trace elements within the mylonite/mylonite with ultramylonite bands. $U M B$ ultra-mylonite bands, $P F G$ porphyroclastic fine-grained, $C$ central, $N$ north

statistically significant. A similar observation can be made for the average $\mathrm{CaO}$ and $\mathrm{MgO}$ composition. This may indicate the possibility of melt addition in the peridotite and preferentially in the deformed rocks. If the melt focusing hypothesis of Kaczmarek and Müntener (2008) is correct, the data indicate a more homogeneous composition and equilibration of deformed rocks.

The peridotites from this study and Piccardo et al. (2007a) display heterogeneous $\mathrm{TiO}_{2}$ composition and are not residues after simple melting of primitive mantle (Fig. 8a). The Lanzo south peridotites display more refractory compositions than samples from porphyroclastic areas. Porphyroclastic peridotites form Lanzo north with a very low $\mathrm{TiO}_{2}$ content contain clinopyroxenes with a high $(\mathrm{Sm} / \mathrm{Yb})_{N}$ ratio suggesting alkaline affinity for some pyroxenes (as discussed by Piccardo et al. 2007b, Fig. 8a). The deformed peridotites are enriched in $\mathrm{TiO}_{2}$ and display low $\mathrm{Cr}$ content in orthopyroxenes (Fig. 8b). The enrichment in incompatible element (Ti) and depletion in compatible element $(\mathrm{Cr})$ suggests a higher fraction of melt that percolated in deformed areas relative to the porphyroclastic areas.

Whole rock trace element variability

The plagioclase peridotites of the Northern and Central Lanzo massif are distinguished from Lanzo South peridotite by overall higher REE content, a far less frequent occurrence of refractory harzburgite and dunite, and a remarkable constant $(\mathrm{Ce} / \mathrm{Yb})_{N}$ ratio (e.g. Bodinier 1988). In addition, each class of deformation contains samples that are enriched in REE as compared to primitive mantle estimates (Fig. 5). Bodinier (1988) argued that the regional-scale zoning in $\mathrm{Ce} / \mathrm{Yb}$ may reflect an enrichment event that preferentially affected the northern body, or alternatively, an early melting episode in the garnet stability field that affected the southern part of the massif. These features are not consistent with simple melting models.

The fertile compositions of some of the plagioclase peridotites might be explained by a "marble cake" model composed of heterogeneously distributed pyroxenites mixed with peridotite as suggested by Allègre and Turcotte (1986). In their view, pyroxenites might represent stretched stripes of 'oceanic crust' that was recycled through the mantle. However, there is no major element nor isotopic evidence for the involvement of oceanic crust in the 
Fig. 7 Bulk rock major and trace elements peridotite compositions along a cross section of the shear zone from SW (a) to NE (a') (See location on Fig. 2). a Schematic topography of the shear zone cross section (after Kaczmarek and Müntener 2008). Chemical composition in b $\mathrm{MgO}$ (wt\%), $\mathbf{c}$ $\mathrm{Al}_{2} \mathrm{O}_{3}(\mathrm{wt} \%)$ and $\mathbf{d ~} \mathrm{Yb}(\mu \mathrm{g} / \mathrm{g})$ for peridotites subdivided by microstructure type. Note that peridotite samples are grouped along the section as a function of distance, with deformed rocks displaying more homogeneous compositions than porphyroclastic rocks. $P$ porphyroclastic, $P F G$ porphyroclastic fine-grained; $U M B$ ultra-mylonite bands
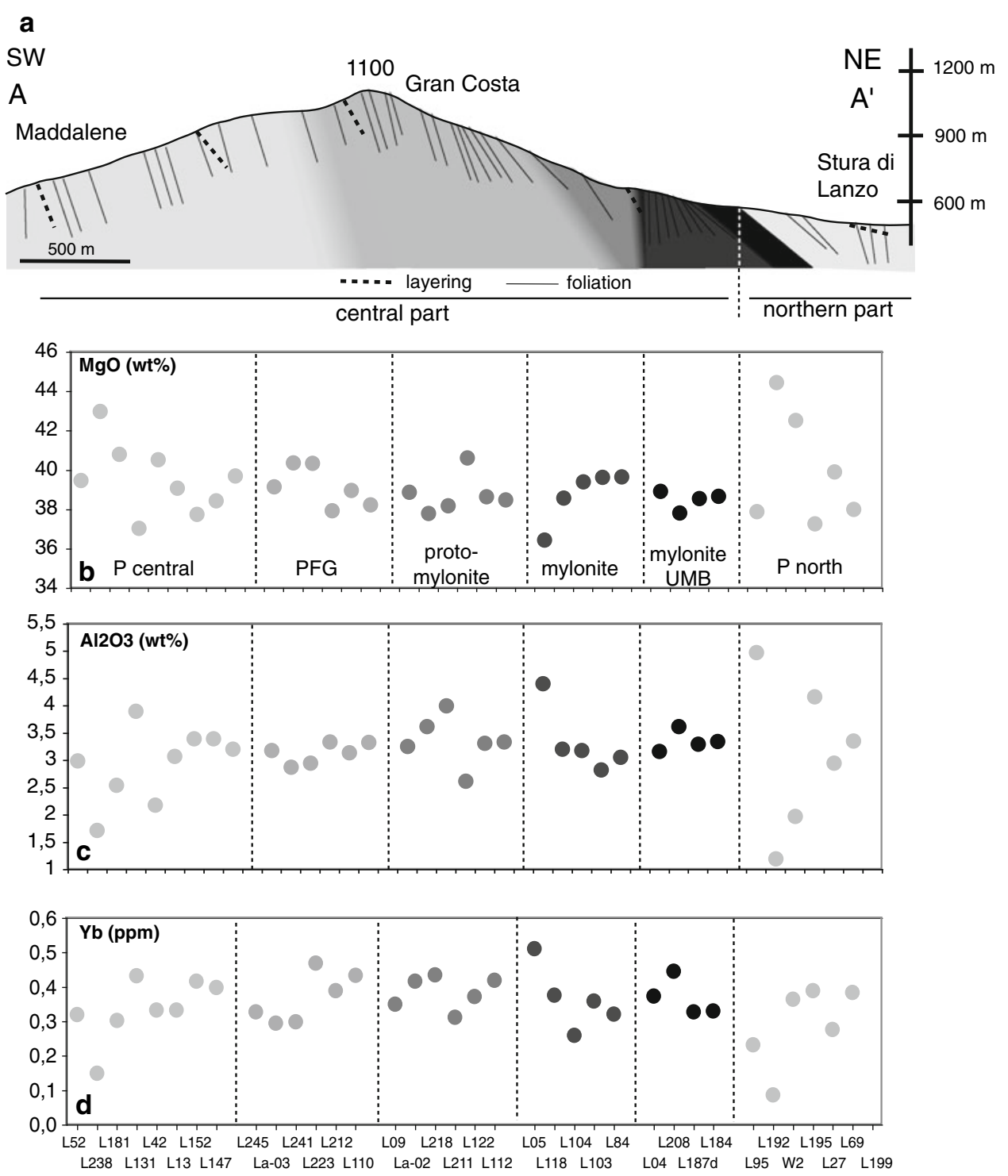

pyroxenite compositions (Bodinier 1988; Bodinier et al. 1991) and the pyroxenite layers were excluded from the sampling. In the case of mylonite, it might be difficult to identify small remnants of disrupted pyroxenite layering in the field, but careful inspection of mineral chemistry indicates that spinel from pyroxenites is generally rich in $\mathrm{Al}$ and particularly low in $\mathrm{Cr}$, and could clearly be distinguished from spinel in peridotite (Kaczmarek and Müntener 2008). Such samples with a "pyroxenite signature" have been excluded from our dataset.

An alternative hypothesis to explain the HREE enrichment in plagioclase peridotite is refertilization by diffuse porous melt flow. The melt/rock reaction and the melt migration textures are frequent in the Lanzo peridotite massif and are commonly illustrated by (1) the occurrence of orthopyroxene + plagioclase intergrowth replacing clinopyroxene and (2) vermicular orthopyroxene replacing olivine porphyroclasts (e.g. Müntener and Piccardo 2003; Piccardo et al. 2004b; Kaczmarek and Müntener 2008). Recent textural and geochemical investigations proposed that refertilization by basaltic or refractory melts is also an important process in abyssal peridotites (Hellebrand et al. 2002; Kelemen et al. 2004; Seyler et al. 2007), which have been conventionally interpreted as simple residues of partial melting (Johnson et al. 1990; Johnson and Dick 1992). Reactive porous flow and refertilization are two important processes that are able to deeply modify textures, mineral modes and chemical compositions of peridotites (Van der Wal and Bodinier 1996; Bedini et al. 1997; Godard et al. 2000; Dijkstra et al. 2002; Müntener and Piccardo 2003; Piccardo et al. 2004b, 2007a). The rocks do not reveal a substantial $\mathrm{Ce} / \mathrm{Yb}$ fractionation, which is consistent with a refertilization hypothesis. If correct, this hypothesis requires adding melt fractions of 

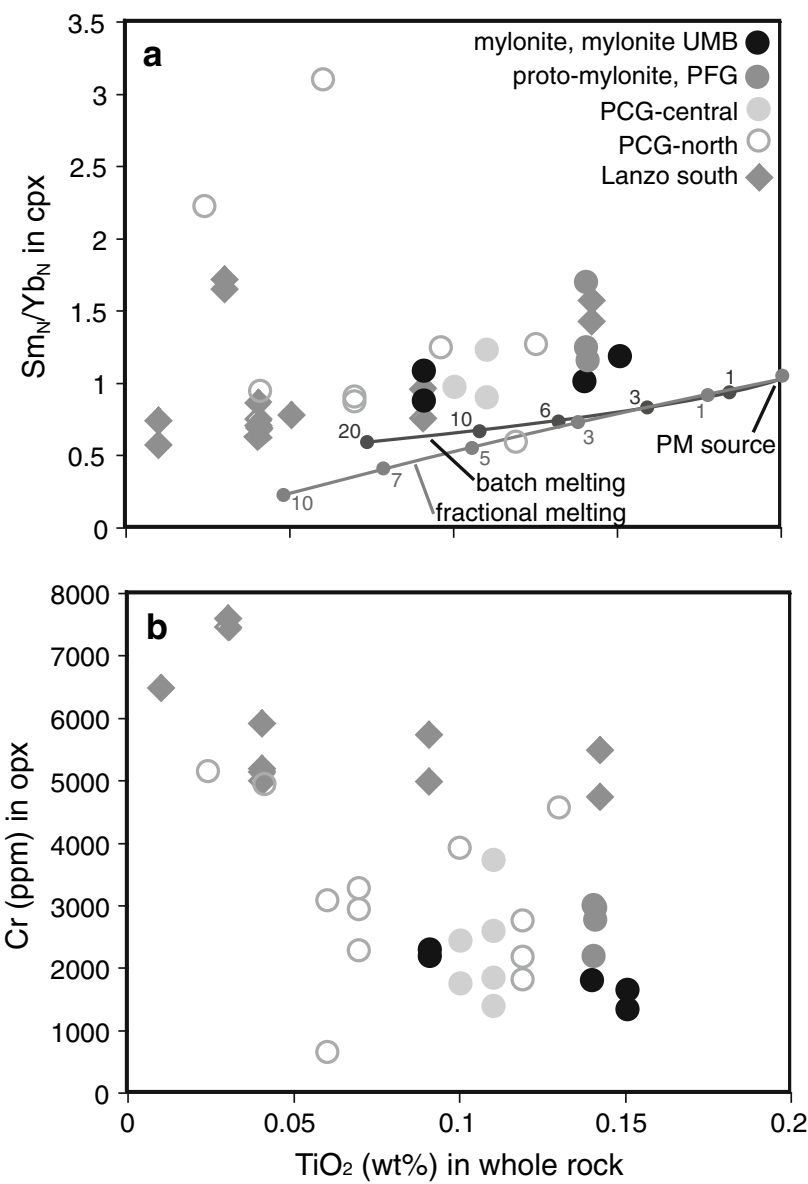

Fig. 8 Trace element in clinopyroxene and orthopyroxene versus whole rock $\mathrm{TiO}_{2}$ for the Lanzo peridotites. Data from Lanzo north (Piccardo et al. 2007b) and Lanzo south (Piccardo et al. 2007a) are reported for comparison. Simple fractional melting with primitive mantle and depleted MORB mantle are shown for illustration purposes only (PM, McDonough and Sun 1995; DMM, Sun and McDonough 1989). Symbols on the modeling curve represent fractionation steps in \%. $P$ porphyroclastic, $P F G$ porphyroclastic fine-grained, $U M B$ ultra-mylonite bands

closely similar composition and thus chromatographic processes (e.g. Navon and Stolper 1987) are unlikely to be important in our case.

The average REE and Y content indicates a slightly depleted composition of the northern body relative to the central body, the difference being most obvious when comparing ultra-mylonite and porphyroclastic rocks (Fig. 7d). These observations suggest that deformation controls, or is linked with the chemical composition, and we propose that the mylonite zone might have acted as a melt conduit. This will be substantiated below, and we discuss additional observations in support of this hypothesis.

$\mathrm{Ce}$ versus $\mathrm{Nb}$ and $\mathrm{Th}$ diagrams indicate a general positive trend from highly depleted peridotite to fertile peridotite (Fig. 9). Refractory peridotite from the Oman
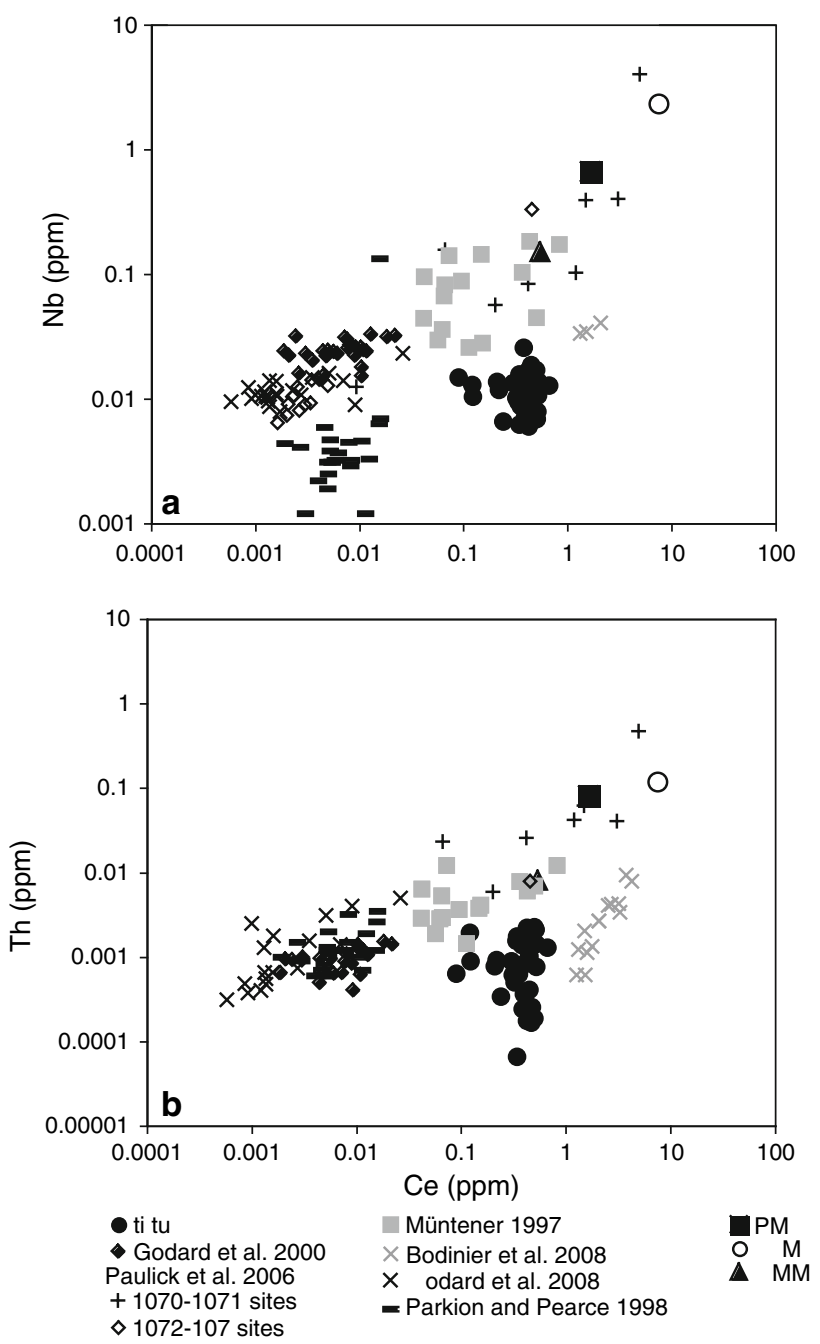

Fig. 9 Trace element variations diagrams of trace elements. a, b $\mathrm{Nb}$ and $\mathrm{Th}$ versus $\mathrm{Ce}(\mathrm{ppm})$ and $\mathbf{c} \mathrm{Ce}_{N}$ versus $[\mathrm{Ce} / \mathrm{Yb}]_{N}$. The Lanzo peridotite massif is compared to published data from the Lherz (Bodinier et al. 2008) and Malenco massifs (Müntener 1997), from the Mid-Atlantic Ridge (Godard et al. 2008; Paulick et al. 2006) and the Oman ophiolite (Godard et al. 2000) and peridotite from a suprasubduction zone (Izu-Bonin-Mariana) (Parkinson and Pearce 1998). Note that all analyses were performed at the Montpellier 2 University except (Parkinson and Pearce 1998). PM (McDonough and Sun 1995) DMM and N-MORB (Sun and McDonough 1989) are shown for references

ophiolite or the Mid-Atlantic Ridge (Godard et al. 2000, 2008) displays low $\mathrm{Ce}$, $\mathrm{Th}$ and $\mathrm{Nb}$ values contrary to harzburgite from the Mid-Atlantic Ridge (Paulick et al. 2006), which presents high $\mathrm{Ce}$, Th and $\mathrm{Nb}$ contents, particularly for ODP leg sites 1270-1271. The most depleted peridotite from the Mid-Atlantic Ridge (Godard et al. 2008) recorded a high degree of partial melting and melt extraction, similar to the peridotites from ODP leg 210 (Müntener and Manatschal 2006). At a given Ce concentration, the peridotites from supra-subduction zones (Parkinson and Pearce 1998) are depleted in Nb but not in 
Th relative to peridotite from Oman. Our data and those from the Ronda peridotites (Bodinier et al. 2008) record Ce enrichment at low $\mathrm{Th}$ and $\mathrm{Nb}$ concentrations, that are about an order of magnitude lower than DMM estimates (Fig. 9b). The Ce-Th-Nb systematics of these fresh peridotites are probably not formed by interaction with fluids (e.g. Paulick et al. 2006), but rather by melt impregnation.

The large variation of $\mathrm{Pb}$ content in the peridotite is apparently not linked to the degree of deformation. Remarkably, the mylonite with ultra-mylonite bands and mylonite samples show $\mathrm{Nd} / \mathrm{Pb}$ ratios higher than $\mathrm{PM}$ composition. Diffusion rates of $\mathrm{Pb}$ in sulfides (solid or melt) are very fast and samples with $\mathrm{Nd} / \mathrm{Pb}$ lower than $\mathrm{PM}$ are interpreted as having reacted with melt (Hart and Gaetani 2006). The OIB and MORB have markedly higher $\mathrm{Nd} / \mathrm{Pb}$ (15 and 23, respectively) than the primitive mantle (Sun and McDonough 1989) and numerous samples from the Lanzo peridotite display $\mathrm{Nd} / \mathrm{Pb}$ ratios higher than MORB (up to 52.7, eTable 3). This strongly suggests that MORB-type melt impregnated the Lanzo peridotite.

The highly incompatible elements ( $\mathrm{Cs}, \mathrm{Rb}$ and $\mathrm{Ba}$ ) enrichment is probably not related to the variation of deformation and it is likely that such enrichments can be attributed to secondary processes such as serpentinization, oceanic alteration or eventually to contamination by crustal fluids (Sharma and Wasserburg 1996; Gruau et al. 1998).

\section{Melting and refertilization modeling}

In the following, melting models will be discussed, in order to evaluate how the trace elements signatures of the plagioclase peridotite could be generated. Two simple melting models, batch melting and fractional melting are illustrated in Fig. 10, simulating melting in the stability field of spinel peridotite, using a DMM and a PUM source (Sun and McDonough 1989; Workman and Hart 2005, Fig. 10a). Peridotite modes, partition coefficients and melting modes are reported in eTable 5. We used the partition coefficients compiled by Suhr et al. (1998), which are similar to many other partition coefficient determinations for mantle melting.

Melt extraction will lead to rapidly decreasing $(\mathrm{Ce} / \mathrm{Yb})_{N}$ ratios at near constant $\mathrm{Yb}$ concentrations in the peridotites (Fig. 10). The plagioclase peridotites show enrichment in $\mathrm{Yb}$ with a near constant $(\mathrm{Ce} / \mathrm{Yb})_{N}$ ratio. Batch melting models yield a much more moderate fractionation of LREE as compared to HREE, which is shown by the relatively high $(\mathrm{Ce} / \mathrm{Yb})_{N}$ ratio after $1-6 \%$ melting, and a slower decrease of $\mathrm{Yb}$ for a given degree of melting. In contrast to fractional melting, the $(\mathrm{Ce} / \mathrm{Yb})_{N}$ ratio is much less fractionated (e.g., between 10 and $20 \%$ melting: $0.1<(\mathrm{Ce} /$ $\left.\mathrm{Yb})_{N}<0.15\right)$ and only slightly lower than the Lanzo
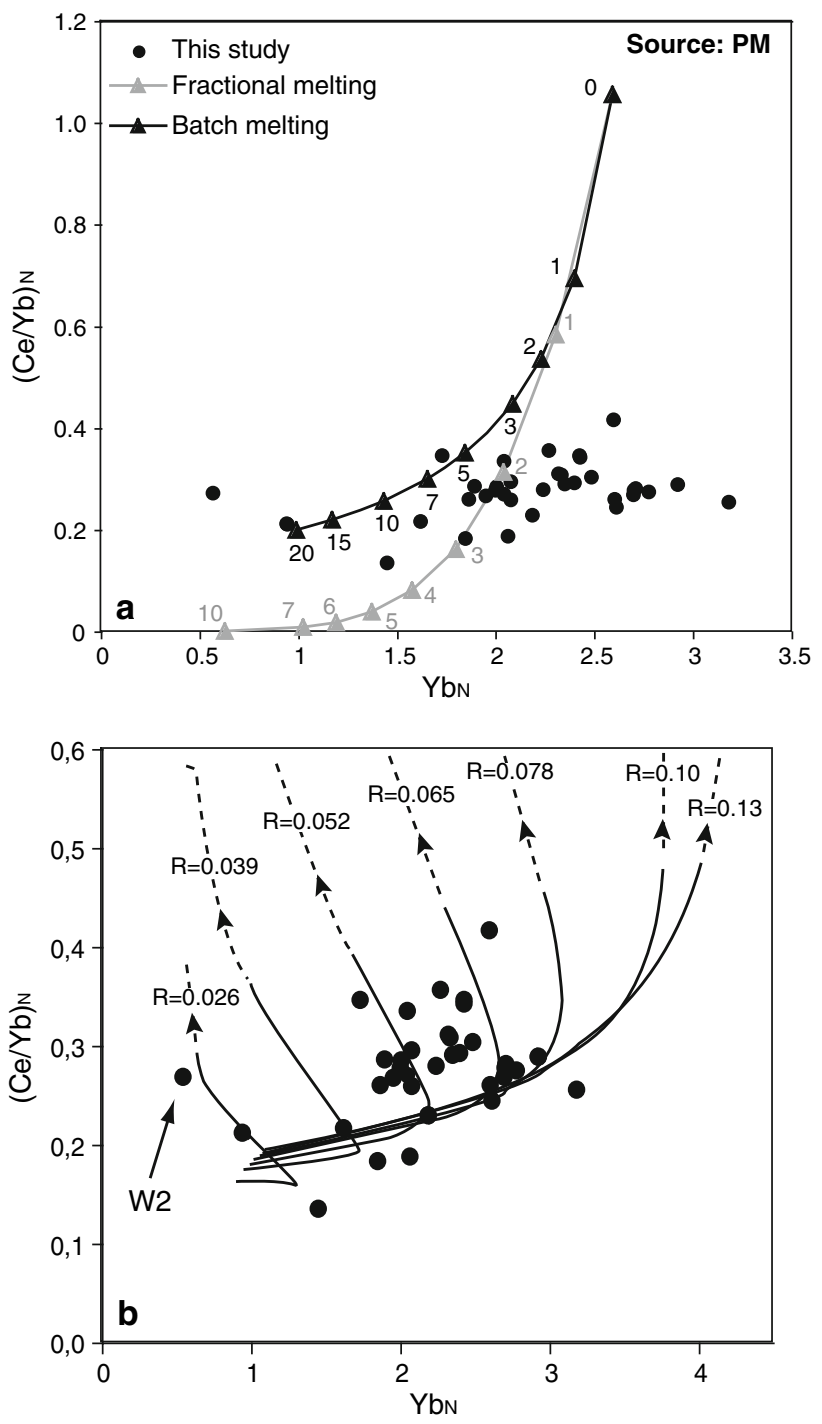

Fig. 10 Illustrations of simple fractional and batch melting models of $\mathrm{Yb}_{N}$ versus $(\mathrm{Ce} / \mathrm{Yb})_{N}$ (a) and numerical modeling of fertilization (b). a Illustrates a model calculated with a PM and a DMM source (PM, McDonough and Sun 1995, DMM Workman and Hart 2005). Symbols on the modeling curve represent fractionation steps in $\%$. b Displays the results of numerical modeling of the $(\mathrm{Ce} / \mathrm{Yb})_{N}$ ratio caused by reactive porous flow modeled with the "Plate model" of Vernières et al. (1997). The protolith affected by the reaction is an olivine-rich harzburgite from this study (W2) with a modal composition of $0.81 \mathrm{ol}, 0.164 \mathrm{opx}, 0.018 \mathrm{cpx}$ and $0.005 \mathrm{plg}$. We applied the (1) melt reaction with ol $=0.3, q_{\mathrm{opx}}=0.65, q_{\mathrm{cpx}}=0.45$ and $q_{\mathrm{plg}}=0.2$, where $\mathrm{Liq}_{\mathrm{i}}$ and $\mathrm{Liq}_{\mathrm{r}}$ are the infiltrated and residual melts, $f$ is the fraction of the percolating melt mass, respectively. The porosity $(\phi)$ is fixed at 0.12 , whereas $f$ was adjusted between 0.9 and 0.98 to allow for variations of $R$, and the enriched plagioclase lherzolite can be obtained by a single run after 60 reaction increments. The curves indicate the results of modeling for different $R$ parameters. $R$ corresponds to the reacted phases as a function of the quantity of melt in the system $\left(R=(1-f) \times\left(q_{\mathrm{opx}}+q_{\mathrm{cpx}}+q_{\mathrm{plg}}\right)\right)$. The arrows on the curves indicate the bottom-to-top cell evolution of melt in the reaction column. Mineral/melt partition coefficients are taken from Hart and Dunn (1993) for a pressure of $3 \mathrm{GPa}$ and a temperature of $1380^{\circ} \mathrm{C}$ 
peridotites. However, more than $70 \%$ of the data have $\mathrm{Yb}$ concentrations that are significantly higher than those obtained by melting models (except assuming a value of $\mathrm{Yb}_{N}$ for the depleted or primitive mantle, that is far higher than any proposed value; e.g. McDonough and Sun 1995; Workman and Hart 2005). After a little percentage of melting (about $1.5 \%$ for a DMM source and 3-5\% using a PUM source by fractional and batch melting, respectively) just some plagioclase peridotite compositions can satisfactorily be explained. More than $70 \%$ of the peridotites

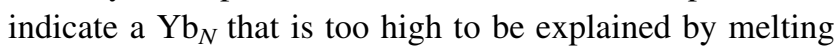
processes alone. We have tested garnet and plagioclase fields melting models, but the results are essentially the same. We tested critical melting models, with residual melt porosities up to $5 \%$, but these calculations do not significantly change the results. The $\mathrm{Yb}_{N}$ enrichment of peridotite is obviously not linked to deformation. However, the (few) depleted rocks are porphyroclastic peridotites. Surprisingly the enriched samples are scattered in the deformed rock type, and the highest $\mathrm{Yb}_{N}$ enrichment and more homogeneous compositions are found in the mylonite samples.

In summary, more than $70 \%$ of the Lanzo plagioclase peridotites cannot be explained by any kind of simple REE melting model, but requires the addition of melt with a relatively constant and high $(\mathrm{Ce} / \mathrm{Yb})_{N}$ ratio (Fig. 10a). To constrain the refertilization processes recorded by the Lanzo peridotite we applied a more complex model simulated with the Plate Model of Vernières et al. (1997, Fig. 10b). We simulate traceelement fractionation during partial melting and reactive porous flow in the Earth's upper mantle. This model was adapted to the simulation of $\mathrm{Fe}-\mathrm{Mg}$ redistribution in peridotite-melt systems by Bedini et al. (2002). Details of the procedure have been reported by Ionov et al. (2005). The modeling permits to simulate melt percolation through and reaction with a peridotite column composed of discrete reaction cells. Minor- and trace-elements variations in solid and melt are controlled by the combined chromatographic effects of melt transport (Navon and Stolper 1987) and the source-sink effects of fractional melt crystallization (Godard et al. 1995; Bodinier et al. 2008). The model was applied to a reaction process involving precipitation of clinopyroxene + orthopyroxene and plagioclase at the expense of melt + olivine. For the 'parallel approach' of Vernières et al. (1997), the reaction takes the general form

$$
\begin{aligned}
& \phi \mathrm{Liq}_{\mathrm{i}}+F(1-\phi) \mathrm{Ol} \rightarrow[f \phi+F(1-\phi)] \mathrm{Liq}_{\mathrm{r}} \\
& \quad+(1-f) \phi q_{\mathrm{opx}}+(1-f) \phi q_{\mathrm{cpx}}+(1-f) \phi q_{\mathrm{plg}}
\end{aligned}
$$

where $\mathrm{Liq}_{\mathrm{i}}$ and $\mathrm{Liq}_{\mathrm{r}}$ stand for the infiltrated and residual (='reacted') melts, respectively. The process is controlled by the fraction of percolating melt mass $(f)$, representing the decrease of melt volume relative to the crystallization of minerals. In this approach, the process is ongoing until the porosity $\left(\phi_{\mathrm{i}}\right)$ approaches 0 , or alternatively, until olivine is entirely dissolved. $F$ is the mass fraction of dissolved olivine (relative to the initial solid matrix) and $q_{\mathrm{opx}}, q_{\mathrm{cpx}}$, $q_{\mathrm{plg}}$ are the crystallized mass fractions of orthopyroxene, clinopyroxene and plagioclase, respectively. Reactions at decreasing melt mass require that $f \phi+F(1-\phi)<\phi$.

The protolith affected by the reaction is considered to be a depleted peridotite such as harzburgite (W2, 80.3 olivine, $16.4 \mathrm{opx}, 1.3 \mathrm{cpx}$ and $0.4 \mathrm{plg}$ ). The refertilization of Lanzo lherzolite is constrained by the $(\mathrm{Ce} / \mathrm{Yb})_{N}$ ratio suggested a slightly enriched (lithospheric) mantle source higher than $\mathrm{N}$-MORB liquid $\left[(\mathrm{Ce} / \mathrm{Yb})_{N} \sim 0.80\right]$ and enriched as E-MORB. We tested an enriched mid-ocean ridge basalt with $(\mathrm{Ce} / \mathrm{Yb})_{N} \sim 1.66$ (Sun and McDonough, 1989), as a potential refertilization agent. The numerical experiment shown in Fig. 10b involves continuous infiltration of enriched melt (E-MORB) and successfully reproduces the compositions of Lanzo peridotites involving pyroxenes and plagioclase forming reaction. Spinel peridotites were transformed to refertilized, impregnated plagioclase peridotites enriched in basaltic components. Several experiments were run with $\mathrm{R}$ values ( $\mathrm{R}$ : mass ratio of precipitated minerals relative to infiltrated melt) ranging from 0.026 to 0.13 (representing a high and low crystallization rate, respectively). The initial stages of the modeling column (e.g., close to the starting compositions) are characterized by a high melt/rock ratio $(>1)$ and represents a rather constant $(\mathrm{Ce} / \mathrm{Yb})_{N}$. In a second part, the modeling indicates a rapid $(\mathrm{Ce} / \mathrm{Yb})_{N}$ enrichment mainly controlled by $\mathrm{Ce}_{N}$ increase in the residual melt related to decreasing melt mass. Most compositional variability of the peridotite can be explained by $R$ varying between 0.052 and 0.078 and by a high melt/rock ratio (e.g., the sub-horizonal parts of the modeling trends). $\mathrm{R}$ is the most sensitive parameter and illustrates that refertilization of the Lanzo peridotite is dependent on the degree of crystallization but also on the quantity of melt percolated. Only few samples require a slightly lower initial $(\mathrm{Ce} / \mathrm{Yb})_{N}$ ratio corresponding to N-MORB compositions (L95, L118, L195, L223) to be modeled successfully. From these models we conclude that N-E MORB percolation is a satisfactory model to explain that variability and refertilization of Lanzo peridotites.

\section{Chemical variability as a function of deformation}

The Lanzo peridotites are characterized by refertilization by N-E MORB percolation and by spatial variations with respect to mineral chemistry and microtextures (Kaczmarek and Müntener, 2008). The authors discussed the effects of deformation on the compositional homogeneity of peridotite minerals. In the mylonite zone, the 
grain size reduction involves homogenization of spinel compositions in terms of $\mathrm{TiO}_{2}$ and $\mathrm{Cr} \#$. Here we illustrate whole rock composition as a function of distance to the shear zone and the deformation classes (Figs. 2, 6, 8). The results display compositional variations at the scale of the Lanzo massif, but a homogenization trend of bulk chemistry in the strongly deformed rocks within the mantle shear zone. Considering the large variability of trace elements as a function of $\mathrm{Al}_{2} \mathrm{O}_{3}$, we observed a systematic correlation relative to the microtextures: the most incompatible elements are well correlated with $\mathrm{Al}_{2} \mathrm{O}_{3}$ in the coarse- and fine-grained rocks. This positive correlation is progressively lost between $\mathrm{Al}_{2} \mathrm{O}_{3}$ and $\mathrm{REE}$ and other incompatible elements (e.g. $\mathrm{Zr}$, La and $\mathrm{Ti}$ ) with increasing deformation (Fig. 6), mainly because of alumina homogenization. The same is observed with compatible elements such as $\mathrm{Ni}$ : the negative correlation with $\mathrm{Al}_{2} \mathrm{O}_{3}$ tends to be lost in the mylonitic rocks.

Interestingly, the $\mathrm{Ce}_{N}$ concentration tends to be more homogeneous with respect to $\mathrm{Yb}_{N}$ with increasing deformation (Fig. 10). This has two important implications: first, the homogenization is unlikely to be caused by simple mechanical mixing, as this process would tend to eliminate the compositional variability of all incompatible elements; second, it is also unlikely, that solid state diffusion can explain the data, as Ce diffuses orders of magnitudes slower than $\mathrm{Yb}$ (Van Orman et al. 2002). If diffusion would be the dominant mechanism one would expect homogenization of $\mathrm{Yb}$ rather than $\mathrm{Ce}$. For these reasons, we prefer the interpretation that deformation occurred in the presence of small melt fractions, which preferentially homogenizes the more incompatible LREE with respect to HREE.

If our refertilization model is correct, then the infiltrating liquid in the Lanzo massif is most probably an E-MORB, and thus different from many xenoliths studies, and also different from liquids that formed the Ronda recrystallization front (Van der Wal and Bodinier 1996; Lenoir et al. 2001). In contrast to the recrystallization front of the Ronda peridotite, which is related to kilometer-scale pervasive melt percolation (Van der Wal and Bodinier 1996), and chromatographic trace element fractionation in the deformed peridotites, the Lanzo mantle shear zone does not show obvious chromatographic effects. We attribute this to the combined effects of melt focusing, rapid cooling and exhumation of the Lanzo peridotites, so that the remaining melt fractions rapidly freeze. This is consistent with disequilibrium spinel compositions (Kaczmarek and Müntener 2008). The stagnating melt probably acts as a lubricant for deformation during the early high temperature stages and at a later stage, cooling and ongoing deformation formed fine grained rocks, which efficiently inhibit upward migration of melt.
Implications

This study provides an explanation for the geochemical variability in peridotite across actively deforming mantle shear zones. Initial pervasive porous flow of melt became focused in time and space (e.g. Kaczmarek and Müntener 2008; Müntener and Piccardo 2003): as documented by impregnation textures in the entire zone, and gabbroic dikes that are much more abundant in the footwall of the shear zone. Melt percolation and refertilization are related to plagioclase crystallization and particularly plagioclase lenses in the most deformed rocks. The presence of plagioclase may influence the localization of deformation during subsequent subsolidus plagioclase-forming reaction, which involves grain-size reduction (Newman et al. 1999). The presence of igneous reaction textures, the localization of deformation and the grain-size reduction all indicate that melt-enhanced deformation played a major role in the evolution of the Lanzo shear zone. Our new results, together with previously published data (e.g. Piccardo et al. 2007a, b) confirm that melt migration occurred on a kilometer-scale over the entire Lanzo massif, but local differences exist. The porphyroclastic peridotite displays a large range of composition, from fertile plagioclase peridotite to refractory harzburgite and dunite, while the deformed peridotite of the shear zone is relatively homogeneous, accentuated by important grain size reduction within the mylonite zone. The northern body is generally less fertile than the central body and represents ancient lithosphere (Bodinier et al. 1991). The trace element composition indicates homogenization in the highly deformed area, and at the same time some accumulation of migrating melt. This might be explained by infiltration and accumulation of melt along the shear zone that acted as a melt conduit.

An important yet unresolved question is to understand whether melt accumulation provided the necessary weakening of the peridotites or high-temperature deformation and shearing formed a permeability barrier for migrating melts. Either way, the presence of melt in the rock will change the rheological behavior and supports further weakening effects. We conclude that a combination of existing heterogeneities (pre-existing shear zones, pyroxenite layers) and thermal gradients might induce the formation of an intra-mantle permeability barrier.

Acknowledgments We thank V. Serneels for providing XRF analyses and A. Ulianov for help with Laser Ablation ICP-MS at Lausanne University. This work benefited from discussions with J.-L. Bodinier (and particularly for fertilization modeling) and M. Godard. Constructive reviews by J. Warren and O. Jagoutz improved the paper and are gratefully acknowledged. This research was financially supported by the Swiss National Science Foundation (Project 21-66923.01, 200020-104636/1 and PP002-102809). 


\section{References}

Allègre CJ, Turcotte DL (1986) Implications of a two-component marble-cake mantle. Nature 323(6084):123-127

Beccaluva L, Macciotta G, Piccardo GB, Zeda O (1984) Petrology of lherzolitic rocks from the Northern Apennine ophiolites. Lithos 17:299-316

Bedini RM, Bodinier JL, Dautria JM, Morten L (1997) Evolution of LILE-enriched small melt fractions in the lithospheric mantle; a case study from the East African Rift. Earth Planet Sci Lett 153(1-2):67-83

Bedini RM, Bodinier JL, Vernières J (2002) Numerical simulation of $\mathrm{Mg}-\mathrm{Fe}$ partitioning during melting and melt-rock reaction in the shallow upper mantle. In: Proceedings of 4th international orogenic lherzolites and mantle processes conference, Japan, Samani (unpublished)

Bodinier JL (1988) Geochemistry and petrogenesis of the Lanzo peridotite body, Western Alps. Tectonophysics 149:67-88

Bodinier JL, Godard M (2003) Orogenic, ophiolitic and abyssal peridotites. Treatise Geochem 2:103-170

Bodinier JL, Menzies MA, Thirlwall MF (1991) Continental to oceanic mantle transition-REE and $\mathrm{Sr}-\mathrm{Nd}$ isotopic geochemistry of the Lanzo lherzolite massif. J Petrol, Special Lherzolite Issue, pp 191-210

Bodinier JL, Garrido C, Chanefo I, Bruguier O, Gervilla F (2008) Origin of pyroxenite-peridotite veined mantle by refertilization reactions: evidence from the Ronda peridotite (Southern Spain). J Petrol 49(5):999-1025

Boudier F (1972) Relations lherzolites-gabbro-dunite dans le massif de Lanzo (Alpes Piémontaises): exemple de fusion partielle. In: Institut des Sciences de la Nature, vol. Université de Nantes, Nantes, p 106

Boudier F (1978) Structure and petrology of the Lanzo peridotite massif (Piedmont Alps). Geol Soc Am 89:1574-1591

Boudier F, Nicolas A (1972) Fusion partielle gabbroique dans la lherzolite de Lanzo (Alpes Piémontaises). Bull Suisse Minéral Pétrograph 52(1):39-56

Boudier F, Nicolas A (1980) Stress and strain estimates in the Lanzo peridotite massif (Western Alps). Colloq Int CNRS 272:221-228

Brown M (1994) The generation, segregation, ascent and emplacement of granite magma: the migmatite-to-crustally derived in thickened orogens. Earth Sci Rev 36:83-130

Dick HJB (1989) Abyssal peridotites, very slow spreading ridges and ocean ridge magmatism. In: Saunders AD, Norris MJ (eds) Magmatism in the Ocean Basins. Geol. Soc. Spec. Publ. 42, London, pp 71-105

Dijkstra HA, Drury MR, Vissers RLM (2001) Structural petrology of plagioclase peridotites in the west Othris Mountains (Greece): melt impregnation in the mantle lithosphere. J Petrol 42(1):5-24

Dijkstra HA, Drury MR, Vissers RLM, Newman J (2002) On the role of melt-rock reaction in mantle shear zone formation in the Othris peridotite massif (Greece). J Struct Geol 24:1431-1450

Elthon D (1992) Chemical trends in abyssal peridotites; refertilization of depleted suboceanic mantle. J Geophys Res 97(6):9015-9025

Frey FA, Suen CJ, Stockman HW (1985) The Ronda high temperature peridotite: geochemistry and petrogenesis. Geochim Cosmochim Acta 49:2469-2491

Godard G, Bodinier JL, Vasseur G (1995) Effects of mineralogical reactions on trace element redistributions in mantle rocks during percolation processes: a chromatographic approach. Earth Planet Sci Lett 133:449-461

Godard M, Jousselin D, Bodinier JL (2000) Relationships between geochemistry and structure beneath a paleo-spreading centre: a study of the mantle section in the Oman ophiolite. Earth Planet Sci Lett 180:133-148
Godard G, Lagabrielle Y, Alard O, Harvey J (2008) Geochemistry of the highly depleted peridotites drilled at ODP sites 1271 and 1274 (Fifteen-Twenty Fracture Zone, Mid-Atlantic Ridge): implications for mantle dynamics beneath a slow spreading ridge. Earth Planet Sci Lett 267(3-4):410-425

Gruau G, Bernard-Griffiths J, Lecuyer C (1998) The origin of Ushaped rare earth patterns in ophiolite peridotites: assessing the role of secondary alteration and/melt rock reaction. Geochim Cosmochim Acta 62:3545-3560

Hart SR, Dunn T (1993) Experimental cpx/melt partitioning of 24 trace elements. Contrib Mineral Petrol 113(1):1-8

Hart SR, Gaetani GA (2006) Mantle Pb paradoxes: the sulfide solution. Contrib Mineral Petrol 152:295-308

Hellebrand E, Snow JE, Mühe R (2002) Mantle melting beneath Gakkel Ridge (Artic Ocean): abyssal peridotite spinel compositions. Chem Geol 182:227-235

Hirth G, Kohlstedt DL (1995) Experimental constraints on the dynamics of the partially molten upper mantle; deformation in the diffusion creep regime. J Geophys Res 100(2):1981-2001

Holtzman BK, Kohlstedt DL (2007) Stress-driven melt segregation and strain partitioning in partially molten rocks: effects of stress and strain. J Petrol 48(12):2379-2406

Holtzman BK, Kohlestedt DL, Zimmerman ME, Heidelbach F, Hiraga T, Hustoft J (2003) Melt segregation and strain partitioning: implications for seismic anisotropy and mantle flow. Science 301:1227-1230

Hutton DHW, Reavy RS (1992) Strike-slip tectonics and granite petrogenesis. Tectonics 11:960-967

Ionov DA, Savoyant L, Dupuy C (1992) Application of the ICP-MS technique to trace element analysis of peridotites and their minerals. Geostand Newsl 16:311-315

Ionov DA, Chanefo I, Bodinier JL (2005) Origin of Fe-rich lherzolites and wehrlites from TOK, SE Siberia by reactive melt percolation in refractory mantle peridotites. Contrib Mineral Petrol 150:335353

Jagoutz E, Palme H, Baddenhausen H, Blum K, Cendales G, Dreibus G, spettel B, Lorenz V, Vanke H (1979) The abundance of major, minor and trace elements in the earth's mantle as derived from primitive ultramafic nodules. Geochim Cosmochim Acta 11:2031-2050

Jochum KP, Seufert HM, Thirlwall MF (1990) Multi-element analysis of 15 international standard rocks by isotope-disolution spark source mass spectrometry. Geostand Newsl 14:469-473

Johnson KTM, Dick HJB (1992) Open system melting and temporal and spatial variation of peridotite and basalt at the Atlantis II fracture zone. J Geophys Res 97(6):9219-9241

Johnson KTM, Dick HJB, Shimizu N (1990) Melting in the oceanic upper mantle: an ion microprobe study of diopsides in abyssal peridotites. J Geophys Res 95(B3):2661-2678

Kaczmarek M-A, Müntener O (2008) Juxtaposition of melt impregnation and high temperature shear zone in the upper mantle; Field and petrological constraints from the Lanzo peridotite $(\mathrm{N}$ Italy). J Petrol 49(12):2187-2220

Kaczmarek M-A, Müntener O, Rubatto D (2008) Trace element chemistry and $\mathrm{U}-\mathrm{Pb}$ dating of zircons from oceanic gabbros and their relationship with whole rock composition (Lanzo, Italian Alps). Contrib Mineral Petrol 155:295-312

Katz RF, Spiegelman M, Holtzman BK (2006) The dynamics of melt and shear localization in partially molten aggregates. Nature 442:676-679

Kelemen PB, Shimizu N, Salters VJM (1995) Extraction of midocean-ridge basalt from the upwelling mantle by focused flow of melt in dunite channels. Nature 375:747-753

Kelemen PB, Koga K, Shimizu N (1997) Geochemistry of gabbro sills in the crust-mantle transition zone of the Oman ophiolite: 
implications for the origin of the oceanic lower crust. Earth Planet Sci Lett 146:475-488

Kelemen PB, Kikawa E, Miller DJ, Abe N, Bach W, Carlson RL, Casey JF, Chambers LM, Cheadle M, Cipriani A, Dick HJB, Faul U, Garces M, Garrido C, Gee JS, Godard M, Graham DW, Griffin DW, Harvey J, Ildefonse B, Iturrino GJ, Josef J, Meurer WP, Mrozewski S, Paulick H, Rosner M, Schroeder T, Seyler M, Takazawa E (2004) ODP Leg 209 drills into mantle peridotite along the Mid-Atlantic Ridge from 14 degrees $\mathrm{N}$ to 16 degrees N. Joint Oceanogr Inst Deep Earth Sampl J 30(1):14-19

Kinzler RJ (1997) Melting of mantle peridotite at pressures approaching the spinel to garnet transition; application to midocean ridge basalt petrogenesis. J Geophys Res 102(1):853-874

Lenoir X, Garrido CJ, Bodinier JL, Dautria JM (2000) Contrasting lithospheric mantle domains beneath the Massif Central (France) revealed by geochemistry of peridotite xenoliths. Earth Planet Sci Lett 181:359-375

Lenoir X, Garrido CJ, Bodinier JL, Dautria JM, Gervilla F (2001) The recrystallization front of the Ronda peridotite: evidence for melting and thermal erosion of subcontinental lithospheric mantle beneath the Alboran basin. J Petrol 42:141-158

McDonough WF, Sun SS (1995) The composition of the Earth. Chem Geol 120:223-253

Müntener O (1997) The Malenco peridotites (Alps): petrology and geochemistry of subcontinental mantle and Jurassic exhumation during rifting. Ph.D. ETH Zurich

Müntener O, Manatschal G (2006) High degrees of melting recorded by spinel harzburgites of the Newfoundland margin: the role of inheritance and consequences for the evolution of the southern North Atlantic. Earth Planet Sci Lett 252:437-452

Müntener O, Piccardo GB (2003) Melt migration in ophiolitic peridotites: the message from Alpine-Apennine peridotites and implications for embryonic ocean basins. In: Dilek Y, Robinson PT (eds) Ophiolites in Earth History. Special publication 218. Geological Society of London, London, pp 69-89

Müntener O, Pettke T, Desmurs L, Meier M, Schaltegger U (2004) Refertilization of mantle peridotite in embryonic ocean basins: trace element and $\mathrm{Nd}$ isotopic evidence and implications for crust-mantle relationships. Earth Planet Sci Lett 221:293-308

Navon O, Stolper E (1987) Geochemical consequences of melt percolation: the upper mantle as a chromatographic column. J Geol 95(3):285-307

Newman J, Lamb WM, Drury MR, Vissers RLM (1999) Deformation processes in a peridotite shear zone: reaction-softening by an $\mathrm{H}_{2} \mathrm{O}$-deficient, continuous net transfer reaction. Tectonopysics 303:193-222

Nicolas A (1986) A melt extraction model based on structural studies in mantle peridotites. J Petrol 27(4):999-1022

Nicolas A (1989) Structures of ophiolites and dynamics of oceanic lithosphere, vol 4. Kluwer Academic Publishers, Dordrecht, p 367

Nicolas A, Dupuy C (1984) Origin of ophiolitic and oceanic ophiolites. Tectonophysics 110(3-4):177-187

Niu YL (2004) Bulk-rock major and trace element compositions of abyssal peridotites: implications for mantle melting, melt extraction and post-melting processes beneath mid-ocean ridges. J Petrol 45(12):2423-2458

Niu YL, Langmuir CH, Kinzler RJ (1997) The origin of abyssal peridotites: a new perspective. Earth Planet Sci Lett 152:251265

Parkinson IJ, Pearce JA (1998) Peridotites from the Izu-BoninMariana forearc (ODP Leg 125): evidence for mantle melting and melt-mantle interaction in a supra-subduction zone setting. J Petrol 39(9):1577-1618

Paulick H, Bach W, Godard G, De Hoog JCM, Suhr G, Harvey J (2006) Geochemistry of abyssal peridotites (Mid-Atlantic Ridge, $15^{\circ} 20^{\prime} \mathrm{N}$, ODP Leg 209): implications for fluid/rock interaction in slow spreading environments. Chem Geol 234:179-210

Piccardo GB, Müntener O, Zanetti A (2004a) Alpine-Apennine ophiolitic peridotites: new concepts on their composition and evolution. Ofioliti 29(1):63-74

Piccardo GB, Müntener O, Zanetti A, Romairone A, Bruzzone S, Poggi E, Spagnolo G (2004b) The Lanzo south peridotite: melt/ peridotite interaction in the mantle lithosphere of the Jurassic Ligurian Tethys. Ofioliti 29(1):37-62

Piccardo GB, Zanetti A, Müntener O (2007a) Melt/peridotite interaction in the Southern Lanzo peridotite: field, textural and geochemical evidence. Lithos 94(1-4):181-209

Piccardo GB, Zanetti A, Pruzzo A, Padovano M (2007b) The North Lanzo peridotite body (NW Italy): lithospheric mantle percolated by MORB and alkaline melts. Period Mineral 76:175-196

Pognante U, Rösli U, Toscani L (1985) Petrology of ultramafic and mafic rocks from the Lanzo peridotite body (western Alps). Lithos 18:201-214

Rampone E, Romairone A, Abouchami W, Piccardo GB, Hofmann AW (2005) Chronology, petrology and isotope geochemistry of the Erro-Tobbio peridotites (Ligurian Alps, Italy): records of late Paleozoic lithospheric extension. J Petrol 46(4):799-827

Rosenberg C, Handy MR (2005) Experimental deformation of partially melted granite revisited: implications for the continental crust. J Metamorph Geol 23:19-28

Seyler M, Cannat M, Mével C (2003) Evidence for major-element heterogeneity in the mantle source of abyssal peridotites from the Southwest Indian Ridge ( $52^{\circ}$ to $68^{\circ} \mathrm{E}$ ). Geochem Geophys Geosyst 4(2):1-33

Seyler M, Lorand JP, Dick HJB, Drouin M (2007) Pervasive melt percolation reactions in ultra-depleted refractory harzburgites at the Mid-Atlantic ridge, $15^{\circ} 20^{\prime} \mathrm{N}$ : ODP Hole 1274A. Contrib Mineral Petrol 153:303-319

Sharma M, Wasserburg GJ (1996) The neodymium isotopic compositions and rare earth patterns in highly depleted ultramafic rocks. Geochim Cosmochim Acta 60(22):4537-4550

Suhr G, Seck HA, Shimizu N, Günther D, Jenner G (1998) Infiltration of refractory melts into the lowermost oceanic crust; evidence from dunite- and gabbro-hosted clinopyroxenes in the Bay of Islands Ophiolite. Contrib Mineral Petrol 131(2-3):136-154

Sun SS, McDonough WF (1989) Chemical and isotopic systematics of oceanic basalts: implications for mantle composition and processes. In: Sanders AD, Norry MJ (eds) Magmatism in the ocean basins. Special Publication 42. Geological Society of London, London, pp 313-345

Van Achterbergh E, Ryan CG, Jackson SE, Griffin WL (2001) Data reduction software for LA-ICP-MS. In: Sylvester PJ (ed) Laserablation-ICPMS in the Earth Sciences. Principles and applications. Mineralogical Association of Canada Short Course vol 29, pp 239-243

Van der Wal D, Bodinier JL (1996) Origin of the recrystallization front in the Ronda peridotite by $\mathrm{km}$-scale pervasive porous melt flow. Contrib Mineral Petrol 122:387-405

Van Orman JA, Grove TL, Shimizu N (2002) Diffusive fractionation of trace elements during production and transport of melt in Earth's upper mantle. Earth Planet Sci Lett 198:93-112

Vernières J, Godard M, Bodinier JL (1997) A plate model for the simulation of trace element fractionation during partila melting and reactive magma transport in the Earth's upper mantle. J Geophys Res 102:24771-27784

Warren JM, Hirth G (2006) Grain size sensitive deformation mechanisms in naturally deformed peridotites. Earth Planet Sci Lett 248:438-450

Workman RK, Hart SR (2005) Major and trace element composition of the depleted MORB mantle (DMM). Earth Planet Sci Lett 231:53-72 